\title{
Nitrogen-containing six-membered heterocyclic compounds as corrosion inhibitors for metals in solutions of mineral acids - A review
}

\section{Ya.G. Avdeev}

A.N. Frumkin Institute of Physical Chemistry and Electrochemistry, Russian Academy of Sciences, Leninskii pr. 31, Moscow, 119071 Russian Federation

E-mail: avdeevavdeev@mail.ru

\begin{abstract}
The current state of studies on metal protection from corrosion in mineral acid solutions by six-membered $N$-containing heterocyclic compounds is reviewed. Literature data on the protection of various metals in acid solutions by these compounds are summarized. The specific features of their protective action mechanism are discussed. The feasibility of metal protection by formulations containing these compounds, even in high-temperature corrosion, is noted. $\mathrm{N}$-Containing six-membered heterocyclic compounds are prone to adsorption on metal surfaces from mineral acid solutions. Based on the free adsorption energy values of these corrosion inhibitors (CIs) on metal surfaces, it can be deemed with high probability that they are mostly bound to a metal by physical forces, but upon adsorption on its surface they slow down the cathodic and anodic reactions, and eventually inhibit its corrosion. Compounds containing $\mathrm{S}$ atoms or bulky substituents are most interesting. These compounds are adsorbed on metals more strongly and behave as more efficient CIs. It often happens that such CIs hinder metal corrosion in $\mathrm{HCl}$ solutions but do it much more weakly in $\mathrm{H}_{2} \mathrm{SO}_{4}, \mathrm{HClO}_{4}$, and $\mathrm{H}_{3} \mathrm{PO}_{4}$. A known method for improving the protective effect of $\mathrm{N}$-containing six-membered heterocyclic CIs in these media involves combining them with anionic additives, e.g., halide or rhodanide anions. The heterocycles discussed behave as CIs in "cold" solutions but lose these properties at higher temperatures. Examples of the use of six-membered $\mathrm{N}$-containing heterocycles as CIs of various steels and non-ferrous metals ( $\mathrm{Al}, \mathrm{Cu}, \mathrm{Sn}, \mathrm{Zn}$ and their alloys) are available in literature. The industrial application of individual six-membered $\mathrm{N}$-containing heterocycles and their derivatives for metal protection in acid media is of little promise and is unjustified. It is more appropriate to use these compounds as components of inhibitor mixtures. Mixed CIs containing these compounds can hinder corrosion even in such corrosive media as high-temperature $\mathrm{HCl}$ solutions or hot $\mathrm{H}_{3} \mathrm{PO}_{4}$ solutions. The base for creating prospective mixed corrosion inhibitors for metals in acids should be searched for among six-membered heterocyclic compounds containing two or more nitrogen atoms or compounds obtained from natural raw materials. The bibliography includes 150 references.
\end{abstract}


Key words: acid corrosion, corrosion inhibitors, metals, nitrogen-containing heterocyclic compounds, pyridine, pyrimidine, pyrazine, pyridazine, triazine, tetrazine, quinoline, quinoxaline, acridine.

\section{Introduction}

Solutions of mineral and organic acids currently find extensive use in various spheres of human activity, including the metal industry, housing maintenance and utilities, and oiland-gas sector. Mineral acids are used for scale removal from steels by pickling. Various acid formulations serve for efficient removal of mineral deposits and rust from internal surfaces of various process equipment, including that made of metals. Oil-bearing, gasbearing and water-bearing strata are often treated with acid solutions to stimulate extraction of hydrocarbons and water. During these process operations, the acid contacts metal parts of the equipment used. As a result, metal parts of the equipment are degraded and the acid consumption increases. The only acceptable method of metal protection in these environments involves the use of inhibitors (CIs), i.e., chemical compounds or formulations that, "when present in sufficient concentration in the system, reduce the corrosion rates of metals without changing significantly the concentration of any corrosive reagent" [1]. The general issues of the protection of metals and alloys in aqueous media by inhibitors, as well as the specific mechanisms of action of various CI groups in these media are covered in a monograph [2] and in reviews [3-9]. However, the specifics of CI application for the protection of metals in acid solutions are not considered in those publications.

Metal protection by CIs in acid solutions was covered in most detail in monographs $[10,11]$ and in a review [12], but more than 30 years passed since they were issued. A number of reviews dealing with certain specific CI groups in acids have been published in the past 15 years. They dealt with unsaturated organic compounds [13], acetylenic compounds [14], unsaturated carbonyl compounds [15] and azomethines [15, 16], as well as the specific features of their protective mechanisms.

Phosphoric acid solutions are media where inhibitory protection is difficult. The physicochemical aspects of CI creation for these media are considered in Ref. [17]. Reviews $[18,19]$ deal with a description of the protective properties of CIs recommended for the oil and gas industry. Helpful information is contained in articles, which were claimed to be reviews, dealing with the effect of organic CIs on the electrochemical behavior of steels in acid solutions [20] or considering specific CI groups, such as formulations of organic compounds with halide anions [21], thiourea and thiodiazole derivatives [22], polymeric compounds [23], pharmaceutical agents [24], environmentallyfriendly products [25], and plant extracts [26].

Though numerous reviews dealing with corrosion inhibitors in acid media are available, an important group of organic compounds, namely, nitrogen-containing heterocycles, was covered insufficiently to date. The few available publications include article [13] where data on corrosion inhibition in acid media are briefly generalized and the 
review [27] dealing with the inhibition of steel corrosion in acids by pyrimidine derivatives. It appears important to generalize data on the protection of metals in acid media by six-membered nitrogen-containing heterocyclic compounds (Figure 1), analyze the possible ways for enhancing the protective action, and consider the specific features of the mechanism of their inhibitive action and areas of practical application.

\section{Inhibition of metal corrosion in acid media by six-membered nitrogen-containing heterocyclic compounds}

\section{Simple ring systems}

Pyridine poorly inhibits the corrosion of mild steel in $1.0 \mathrm{M} \mathrm{HCl}\left(25^{\circ} \mathrm{C}\right)$. The protective effect it provides at $C_{\mathrm{in}}=2 \mathrm{mM}$ concentration in the corrosive medium is $Z=14.8 \%$. Replacement of hydrogen atoms in the pyridine molecule by substituents (R) can considerably enhance its protective action. For example, under the same conditions, 2-(4pyridyl)-benzimidazole provides $Z=94.5 \%$, though benzimidazole itself, whose radical was used as the R, provides $Z=23.9 \%$ [29]. However, this effect is not always observed: 2-acetylpyridine and 2-benzoylpyridine weakly affect the corrosion of mild steel [30, 31] and aluminum [32] in cold $\mathrm{HCl}$ solutions.

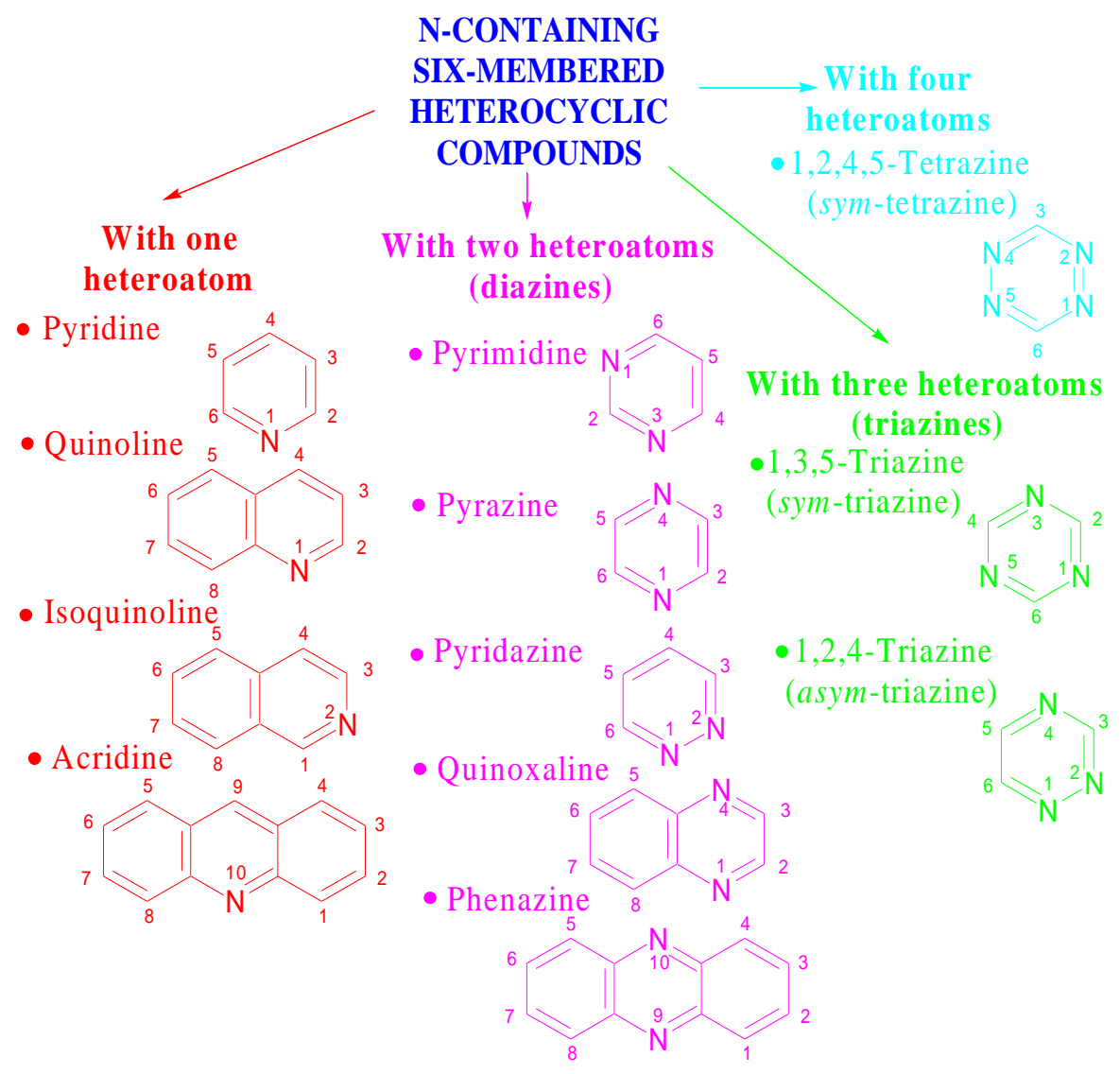

Figure 1. The most important nitrogen-containing six-membered organic heterocycles used as part of corrosion inhibitors [28]. 
The inhibitive properties of sulfur-containing pyridine derivatives have been studied extensively. Pyridine-2-thiol and 2-pyridyl disulfide slow down the corrosion of mild steel in $0.1 \mathrm{M} \mathrm{HCl}$ at room temperature [33]. Isomeric compounds

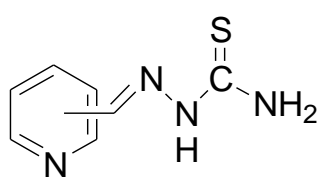

were studied as corrosion inhibitors of mild steel in $1 \mathrm{M} \mathrm{HCl}\left(30^{\circ} \mathrm{C}\right)[34,35]$. According to electrochemical data, their efficiency at $C_{\text {in }}=0.15-1.5 \mathrm{mM}$ depends on the position of $\mathrm{R}$ in the pyridine ring as follows: ortho $>$ meta $>$ para. An increase in $t$ from 30 to $50^{\circ} \mathrm{C}$ can decrease the protective effect of the $o$-isomer and especially the $p$-isomer. The same CIs were studied for aluminum protection in $1.0 \mathrm{M} \mathrm{HNO}_{3}\left(25^{\circ} \mathrm{C}\right)$. According to electrochemical impedance spectroscopy (EIS) data, it decreases in the series of isomers: meta $>$ para $>$ ortho. The most efficient of them provides $Z=44.3-88.4 \%$ at $C_{\text {in }}=0.1-10$ $\mathrm{mM}$ [36]. According to mass loss measurements, 4-pyridinecarboxaldehyde-4-phenylthiosemicarbazide and especially 3-pyridine-carboxaldehyde-4-phenylthiosemicarbazide $\left(C_{\text {in }}=0.1-1.0 \mathrm{mM}\right)$ efficiently inhibit the corrosion of mild steel in $1 \mathrm{M} \mathrm{HCl}\left(30-50^{\circ} \mathrm{C}\right)$, though there protective effects also decrease somewhat with a temperature growth [37]. 2,5-bis(4-Pyridyl)-1,3,4-thiadiazole $(C=0.2-1.2 \mathrm{mM})$ slows down the corrosion of mild steel in $1 \mathrm{M} \mathrm{HCl}\left(30^{\circ} \mathrm{C}\right)$. Its efficiency is somewhat lower in $0.5 \mathrm{M} \mathrm{H}_{2} \mathrm{SO}_{4}$, and it can stimulate corrosion in $1 \mathrm{M} \mathrm{HClO}_{4}$. According to voltammetric curves of steel, the increase in the corrosion rate in $1 \mathrm{M} \mathrm{HClO}_{4}$ in the presence of this compound may be due to a cathodic reduction of this CI [38]. According to EIS data, 2,5-bis(2-pyridyl)-1,3,4-thiadiazole and especially 2,5-bis(3-pyridyl)-1,3,4-thiadiazole are more efficient in corrosion inhibition. Their protective action also decreases in the series of acids: $1 \mathrm{M} \mathrm{HCl}>0.5 \mathrm{M}$ $\mathrm{H}_{2} \mathrm{SO}_{4}>1 \mathrm{M} \mathrm{HClO}_{4}$. In this case, 2,5-bis(2-pyridyl)-1,3,4-thiadiazole in $1 \mathrm{M} \mathrm{HClO}_{4}$ is rather a strong stimulator of steel corrosion [39].

According to electrochemical studies, including EIS, 2-pyridinecarbonitrile $\left(C_{\text {in }}=\right.$ $0.5-10 \mathrm{mM})$ inhibits the corrosion of mild steel in $0.1 \mathrm{M} \mathrm{HCl}\left(25^{\circ} \mathrm{C}\right)$ [40]. Under these conditions, pyridine carbonitriles with more complex compositions inhibit the corrosion and electrode reactions of steel in more concentrated solutions: 1-2 $\mathrm{M}[41,42]$ and even $15 \% \mathrm{HCl}[43]$.

Low efficiency in the inhibition of the corrosion of Q235 mild steel (composition, mass\%: $\mathrm{C}$ 0.14-0.22; Mn 0.30-0.65; Si up to 0.3; $\mathrm{S}$ up to $0.5 ; \mathrm{P}$ up to 0.045 ) in $1 \mathrm{M} \mathrm{HCl}$ $\left(35-55^{\circ} \mathrm{C}\right)$ is observed for the high-molecular compound 4-[((4-(bis(pyridin-2-ylmethyl)amino)phenyl)imino)methyl]- $N, N$-diethylaniline $\left(C_{\text {in }}=0.1-1 \mathrm{mM}\right)$ 


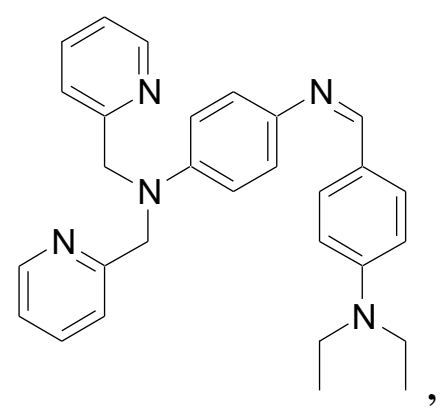

whose $Z$ is $\leq 92 \%$ [44].

In USSR, corrosion inhibitors of Katapin series were developed for the protection of various steels in acid solutions $[11,45]$. They were obtained from pyridine and produced on industrial scale. Katapins $\mathrm{A}(n=8-10)$ and $\mathrm{K}(n=4-6)$ were produced on the basis of para-alkylbenzylpiridinium chlorides $\left(\left[\mathrm{H}_{3} \mathrm{C}-\left(\mathrm{CH}_{2}\right)_{n}-\mathrm{CH}_{2}-\mathrm{C}_{6} \mathrm{H}_{4}-\mathrm{CH}_{2}-\mathrm{NC}_{5} \mathrm{H}_{5}\right] \mathrm{Cl}\right)$, while Katapins B-300 $(n=6-8, m=2-5), \mathrm{BPV}$ and EPV differing in the production technology were obtained from alkylpolybenzylpyridinium chlorides $\left(\mathrm{C}_{n} \mathrm{H}_{2 n+1}-\mathrm{CH}_{2}-\left(\mathrm{C}_{6} \mathrm{H}_{4}-\mathrm{CH}_{2}\right)_{m}-\right.$ $\left.\mathrm{NC}_{5} \mathrm{H}_{5}\right] \mathrm{Cl}$ ). Furthermore, corrosion inhibitors of brands I-A, I-V, and I-E were produced on the basis of polyalkylpyridines with different degrees of modification, as well as the KPI-3 inhibitor was obtained from a quaternary pyridinium salt.

Pyridinium salts with the composition

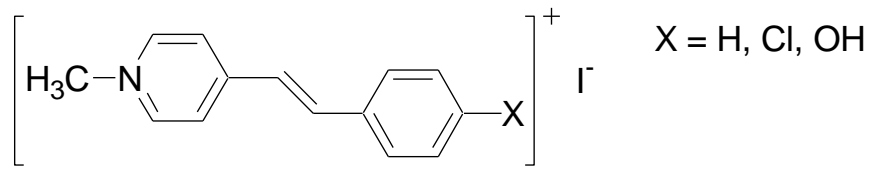

were studied as $\mathrm{CIs}$ for an $\mathrm{Al}-\mathrm{Cu}$ alloy (composition, mass\%: $\mathrm{Cu} 4.32 ; \mathrm{Mg} \mathrm{0.21;} \mathrm{Pb} 0.072$; Fe 0.099; Mn 0.223; Si 0.634) in 0.5 M HCl. According to the data of EIS, mass loss and voltammetric studies, these compounds provide $Z>94 \%$ at $C_{\text {in }}=0.25 \mathrm{mM}$ and $t=30^{\circ} \mathrm{C}$. The protective effects of the CIs increase in the series of $\mathrm{R}: \mathrm{H}>\mathrm{Cl}>\mathrm{OH}$. The protective effects of these compounds decrease with an increase in temperature. For the most efficient CI, 1-methyl-4[4'(-OH)-styryl]pyridinium iodide, an increase in $t$ from 30 to $70^{\circ} \mathrm{C}$ decreases $Z$ from 98.2 to $82.8 \%$ [46].

Among pyrimidine derivatives, compounds with amino groups have been studied most thoroughly. The protective effect of $1 \mathrm{mM} 2$-aminopyrimidine for Armco iron in $2 \mathrm{M}$ $\mathrm{HCl}\left(40^{\circ} \mathrm{C}\right)$ is as low as $Z=28 \%$. Even poorer protection $(Z=24 \%)$ is provided by $2,4,6-$ triaminopyrimidine. The protective effect of substituted pyrimidines can be enhanced by combining a few amino and thiol groups in their structures ( $Z(2,4$-diamino-6mercaptopyrimidine $)=39 \%, Z(2,6$-dimercapto-4,5-diaminopyrimidine $)=40 \%)$, though thiols are more efficient: 2,4-dimercaptopyrimidine, $Z=43 \% ; 2$-mercaptopyrimidine, $Z=$ $62 \%$ [47-49]. In $1 \mathrm{M} \mathrm{HCl}\left(20^{\circ} \mathrm{C}\right), 0.5 \mathrm{mM} \mathrm{2-amino-4,6-dihydroxypyrimidine} \mathrm{provides}$ good protection of carbon steel, $Z=94.5 \%$, but at $t=50^{\circ} \mathrm{C}$ it decreases to $79.5 \%$ [50]. According to electrochemical studies, in $0.5 \mathrm{M} \mathrm{H}_{2} \mathrm{SO}_{4}\left(20^{\circ} \mathrm{C}\right) 10 \mathrm{mM}$ 2-aminopyrimidine and 2,4-diaminopyrimidine hinder the corrosion of cold rolled steel (composition, mass\%: 
C 0.07; Si 0.01; $\mathrm{Mn} 0,3 ; \mathrm{P} 0.022 ; \mathrm{S} 0,010 ; \mathrm{Al} \mathrm{0.030)}$ to reach $Z=82.0$ and $89.6 \%$, respectively [51]. In dilute $0.05 \mathrm{M} \mathrm{HNO}_{3}\left(30^{\circ} \mathrm{C}\right)$ on 1018 carbon steel (composition, mass\%: C 0.2; Si 0.003; Mn 0.6; P 0.04) at $C_{\text {in }}=17 \mu \mathrm{M}$, protection increases in the series: 2-aminopyrimidine $<2$,4-diaminopyrimidine $<2$,4-diamino-6-hydroxypyrimidine $<2,4,6$ triaminopyrimidine, the observed effects being $Z=36.3,42.7,48.5$ and $53.3 \%$, respectively. The protective effects of these compounds can be improved by addition of 1 $\mathrm{mM} \mathrm{KI}$ to reach $Z_{\mathrm{mix}}=51.0,62.0,66.0$ and $75.0 \%$ [52]. The simplest way of chemical modification of amines is to convert them to azomethines. According to mass loss measurements, in $2 \mathrm{M} \mathrm{HCl}\left(25^{\circ} \mathrm{C}\right)$ the inhibitive effect on the corrosion of carbon steel (composition, mass\%: C 0.2; Si 0.003; Mn 0.35; P 0.024) of azomethines obtained from 4,6-dimethylpyrimidine-2-amine decreases in the series: $N$-benzylidene-4,6dimethylpyrimidine-2-amine $>2$-[(3,6-Dimethylpyridimine-2-ylimino)methyl $]-4-$ nitrophenol $>4,6$-Dimethylpyrimidine-2-amine. At $C_{\text {in }}=5 \mathrm{mM}, Z=93.3,73.4$ and 70.6\%, respectively [53]. Substituted 2-aminopyrimidines
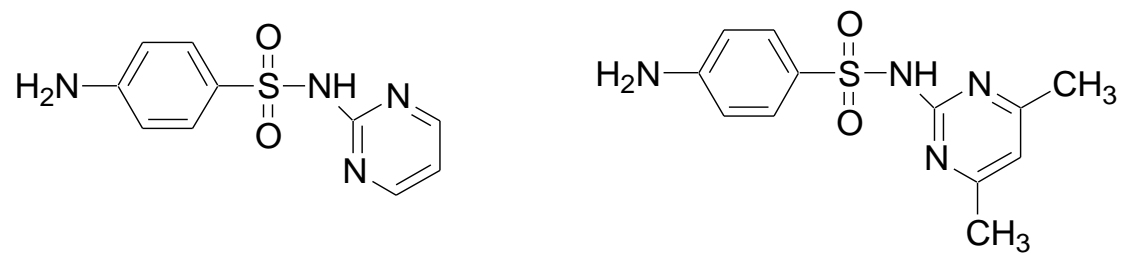

have been studied as corrosion inhibitors of mild steel in $1 \mathrm{M} \mathrm{HCl}$ and $0.5 \mathrm{M} \mathrm{H}_{2} \mathrm{SO}_{4}$ $\left(25^{\circ} \mathrm{C}\right)$. The first compound is more efficient in both acids, and both CIs hinder the corrosion in $1 \mathrm{M} \mathrm{HCl}$ much better [54].

4-Phenylpyrimidine is more efficient than 5-phenylpyrimidine in corrosion inhibition of cold rolled steel (composition, mass\%: C 0.07; Si 0.01; Mn 0.3; P 0.022; S 0.010; Al $0.030)$ in $\mathrm{HCl}$ solutions. Their protective effects decrease even on increasing $t$ to $50^{\circ} \mathrm{C}$ and $C_{\mathrm{HCl}}$ from 1 to $5 \mathrm{M}[55]$.

Compounds with more complex structures containing a pyrimidine residue were also studied as CIs of various steels in cold $\mathrm{HCl}$ solutions. For example, vitamin $\mathrm{B}_{1}[56,57]$ in $0.5 \mathrm{M} \mathrm{HCl}$ provides $Z=91.5 \%$ only at high $C_{\text {in }}=10 \mathrm{mM}$.

In $\mathrm{HNO}_{3}$ and $\mathrm{H}_{2} \mathrm{SO}_{4}$ solutions, steel protection could be ensured only in the case of sulfur-containing pyrimidine derivatives, such as 2-mercaptopyrimidine [58] and more complex compounds:

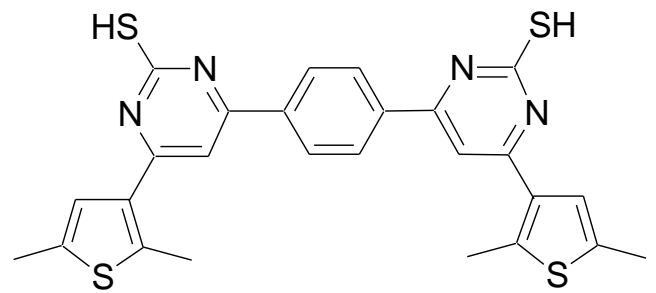

For example, in $0.1 \mathrm{M} \mathrm{HNO}_{3}\left(20-50^{\circ} \mathrm{C}\right)$, addition of $0.5 \mathrm{mM} 2$-mercaptopyrimidine provides $Z \leq 95 \%$ for cold rolled steel, whereas compounds with similar structures such as 
2-chloropyrimidine, 2-hydroxypyrimidine, 2-bromopyrimidine, and 2-aminopyrimidine provide low protection $(Z \leq 35 \%)$ even at $C_{\text {in }}=10 \mathrm{mM}$.

Corrosion inhibitors based on a hydrogenated pyrimidine ring are known. Hydrogenated pyrimidines (3,4-dihydropyrimidine) and their low-molecular derivatives (2mercapto-3,4-dihydropyrimidine, 2-mercapto-3,4-dihydro-6-methylpyrimidine, 2-mercapto4-amino-1,6-dihydropyrimidine, 2,5,6-triamino-3,4-dihydropyrimidine, and 2-mercapto-4amino-5-nitro-1,6-dihydropyrimidine) in $2 \mathrm{M} \mathrm{HCl}\left(40^{\circ} \mathrm{C}\right)$ almost do not affect the corrosion of Armco iron or even accelerate it [47, 48]. Corrosion of mild steel is inhibited more strongly in $2 \mathrm{M} \mathrm{HCl}\left(35-65^{\circ} \mathrm{C}\right)$ by compounds with bulky substituents $\mathrm{R}$, viz., 4substituted 5-acetyl-6-methyl-4-phenyl-3,4-dihydropyrimidin-2 $(1 H)$-ones with phenyl or nitrophenyl substituents. According to mass loss studies at $10 \mathrm{mg} / \mathrm{l}$ of the most efficient one of them, 5-acetyl-6-methyl-4-phenyl-3,4-dihydropyrimidin-2(1H)-one, $Z=99.0 \%$ at $t$ $=35^{\circ} \mathrm{C}$ but as small as $91.0 \%$ at $t=65^{\circ} \mathrm{C}$ [60]. Tetrahydropyrimidine derivatives are even more interesting. According to mass loss measurements and EIS data obtained in $1 \mathrm{M} \mathrm{HCl}$ $\left(25^{\circ} \mathrm{C}\right), \quad 5 \mathrm{mM} \quad$ 5-benzoyl-4-(4-carboxphenyl)-6-phenyl-1,2,3,4-tetrahydro-2-iminopyrimidine or 5-benzoyl-4-tolyl-6-phenyl-1,2,3,4-tetrahydro-2-thioxopyrimidine inhibit the corrosion $(Z \geq 90 \%)$ of stainless steel (composition, mass\%: C 0.0425; Si 0.421; Mn 2.13; P 0.0133; S 0.113; Cr 18.51; Mo 0.563; Ni 8.34; Al 0,0334; Co 0.0901; Cu 0.358) [61]), a material that is difficult to protect. Some tetrahydropyrimidine derivatives
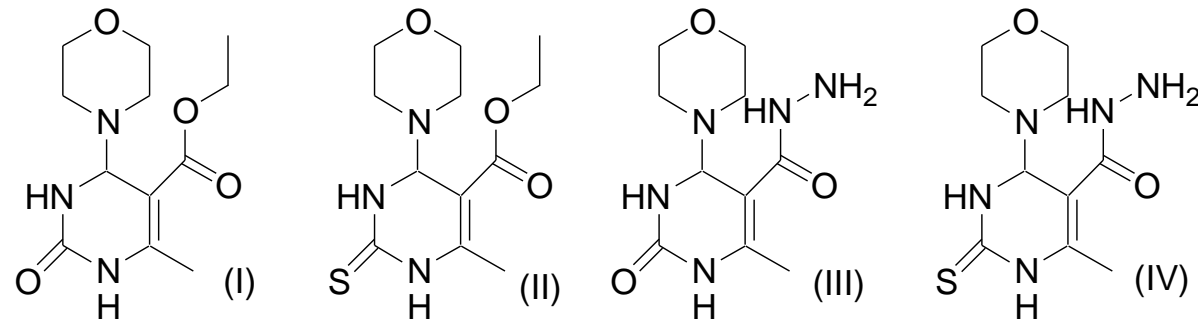

can enhance steel protection with rising temperature. For example, compound IV provides $Z=89.4 \%$ on mild steel in $0.5 \mathrm{M} \mathrm{HCl}$ at $t=30^{\circ} \mathrm{C}$ but $Z=92.4 \%$ at $t=60^{\circ} \mathrm{C}$. The efficiency of the CIs increases in the series: I $<$ II $<$ III $<$ IV. Other conditions being equal, the inhibitive effect of such CIs is improved upon replacement of an oxygen atom with sulfur or an ethoxy group with a hydrazine residue [62]. Conversely, the efficiency of compounds with the structures

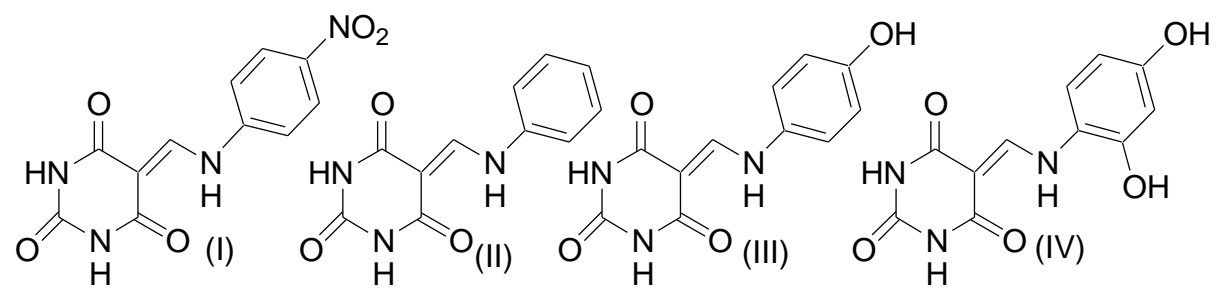

decreases with an increase in $t$ from 35 to $65^{\circ} \mathrm{C}$ and increases in the following series for mild steel protection in $1 \mathrm{M} \mathrm{HCl}$ : (I) $<$ (II) $<$ (III) $<$ (IV) [63]. 
Substituted pyrazines than do not show outstanding protective effects in $\mathrm{H}_{2} \mathrm{SO}_{4}$ solutions (Table 1) [64] have been studied less thoroughly. The protective effects of these CIs are considerably higher in $\mathrm{HCl}$ solutions [65]. The efficiency of CIs decreases in the series 2-amino-5-bromopyrazine $(\mathrm{ABP})>2$-aminopyrazine $(\mathrm{AP})>2$-methylpyrazine (MP), which is in good agreement with the data of quantum-chemical DFT calculations for the molecules of these compounds, as well as by molecular dynamics simulation of interactions between pyrazine molecules and iron surface using materials from Studio 6.0 software [66]. The $-\mathrm{C}=\mathrm{N}-$ atomic group, the $\mathrm{N}$ atom of the amino group, and the $\mathrm{Br}$ atom are considered as the active centers for the adsorption of these CIs. It is assumed that they and $\pi$-electron systems can bind with the metal surface, forming donor-acceptor bonds or providing electrons for the formation of a coordination bond with incomplete d-orbitals of the metal. More rarely, a CI can also be an electron acceptor that accepts electrons from a metal.

Table 1. Binding energies of substituted pyrazine molecules with $\mathrm{Fe}(110)$ surface $\left(E_{\mathrm{binding}}\right)$ based on data of molecular dynamics simulations [66]; protection degree of cold rolled steel* by substituted pyrazines $(1.0 \mathrm{mM})$ in acid solutions $\left(25^{\circ} \mathrm{C}\right)$ based on EIS data $(Z)$; free adsorption energy of pyrazines on steel from acid mixtures $\left(\Delta G_{\text {ads }}\right)[64,65]$.

\begin{tabular}{|c|c|c|c|c|c|c|}
\hline \multirow{2}{*}{ Compound } & \multirow{2}{*}{$\begin{array}{c}\text { Structural } \\
\text { formula }\end{array}$} & \multirow{2}{*}{$\begin{array}{l}E_{\text {binding, }} \\
\text { kJ/mol }\end{array}$} & \multicolumn{2}{|c|}{$1.0 \mathrm{M} \mathrm{H}_{2} \mathrm{SO}_{4}$} & \multicolumn{2}{|c|}{$1.0 \mathrm{M} \mathrm{HCl}$} \\
\hline & & & $Z, \%$ & $\begin{array}{c}\Delta G_{\mathrm{ads}}, \\
\mathrm{kJ} / \mathrm{mol}\end{array}$ & $Z, \%$ & $\begin{array}{c}\Delta G_{\mathrm{ads}} \\
\mathrm{kJ} / \mathrm{mol}\end{array}$ \\
\hline 2-methylpyrazine & & 127.5 & 60.5 & -28.3 & - & - \\
\hline 2-aminopyrazine & & 194.6 & 69.6 & -29.0 & 93.0 & -36.1 \\
\hline $\begin{array}{c}\text { 2-amino-5- } \\
\text { bromopyrazine }\end{array}$ & & 236.2 & 75.3 & -29.7 & 96.0 & -37.5 \\
\hline
\end{tabular}

* composition, mass\%: C 0.07; Si 0.01; Mn 0.3; P 0.022; S 0.010; Al 0.030.

The data obtained show that the energy of pyrazine interaction with the $\mathrm{Fe}(110)$ surface is negative, hence good adsorption of such compounds on the metal surface can be expected. The energy of binding of pyrazines with iron surface increases in the series: MP < $\mathrm{AP}<\mathrm{ABP}$. ABP provides the highest energy of binding with iron surface, which indicates its strong adsorption on the metal surface, hence it should be a more efficient CI than AP and MP. In the case of MP adsorption on iron, the methyl group prevents a parallel orientation of its molecule on the surface. It can be the reason of the lower binding energy obtained for MP adsorption on iron surface in comparison with ABP and AP. Despite the data of quantum-chemical calculations, the experimentally determined adsorption energies 
of the CIs in question on steel surface from acid solutions are high, but insufficient for making the conclusion on the chemisorption nature of their interaction with the surface.

Substituted pyridazines constitute a CI group that is studied better. Of the compounds with similar structures studied

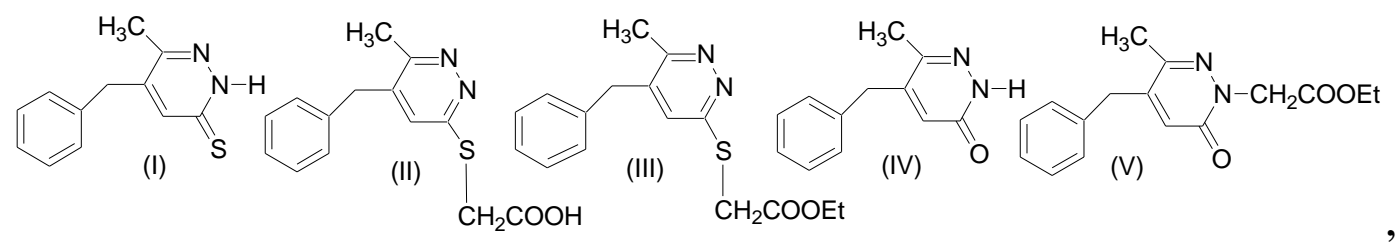

at $C_{\text {in }}=0.1 \mathrm{mM}$, according to mass loss measurements, the corrosion of pure iron $(99.5 \%)$ in $1 \mathrm{M} \mathrm{HCl}\left(25^{\circ} \mathrm{C}\right)$ is inhibited most efficiently by sulfur-containing compounds $\left(Z_{\mathrm{I}}=98 \%\right.$, $\left.Z_{\mathrm{II}}=85 \%, Z_{\mathrm{III}}=81 \%\right)$. In this case, $\mathrm{R}$ substituents at the $\mathrm{S}$ atom weaken the protective effect of CIs. Replacement of an $\mathrm{S}$ atom with $\mathrm{O}$ in a $\mathrm{CI}$ molecule decreases the protective effect $\left(Z_{\mathrm{VI}}=74 \%\right)$. A stronger adverse effect on the CI properties is caused by a substituent at a nitrogen atom in the heterocycle $\left(Z_{\mathrm{V}}=64 \%\right)$ [67, 68]. An increase in the protective effect of pyridazines upon the use of $\mathrm{S}$ as the $\mathrm{R}$ was noted in $[69,70]$. The inhibitory effect of pyridazines decreases with an increase in temperature: the $Z$ value of 5-(2chlorobenzyl)-2,6-dimethylpyridazin-3-one $(1 \mathrm{mM})$ in $1.0 \mathrm{M} \mathrm{HCl}$ for $\mathrm{S} 38$ steel (composition, mass\%: C 0.21; Si 0.38; Mn 0.05; P 0.09; S 0.05; Al 0.01) decreases from 96.1 to $82.8 \%$ upon a temperature increase by $35^{\circ} \mathrm{C}$ [71, 72]. 5-[(2-Chlorophenyl)(hydroxy)methyl]-6-methylpyridazin-3(2H)-one can slow down the corrosion of copper (composition, mass\%: $\mathrm{Cu}$ 99.5; Ni 0.001; $\mathrm{Al} \mathrm{0,019;} \mathrm{Mn} 0.004 ; \mathrm{S} 0.116$ ) in $2.0 \mathrm{M} \mathrm{HNO}_{3}$ $\left(30^{\circ} \mathrm{C}\right)$, giving $Z=94.3 \%$, but $Z=77.6 \%$ at $t=70^{\circ} \mathrm{C}[73]$.

According to corrosion tests in $1 \mathrm{M} \mathrm{HCl}\left(6 \mathrm{~h}, 25^{\circ} \mathrm{C}\right)$ on mild steel, a derivative of hydrogenated pyridazine, 6-methyl-4,5-dihydro- $2 H$-pyridazine-3-one $\left(C_{\text {in }}=0.1-10 \mathrm{mM}\right)$, provides $Z=92-98 \%$, but in $0.5 \mathrm{M} \mathrm{H}_{2} \mathrm{SO}_{4}, Z=21-55 \%$ even at $C_{\text {in }}=0.1-50 \mathrm{mM} \mathrm{[74]}$. More recent studies performed under similar conditions [75] have shown that mild steel protection by $0.5 \mathrm{mM}$ of this compound is even weaker: $Z=17.7 \%$. However, replacement of the methyl in its molecule with the more hydrophobic phenyl and replacement of the $\mathrm{O}$ atom with $\mathrm{S}$ results in $Z=98.0 \%$. An increase in the protective effect is noted in the series of compounds: 6-methyl-4,5-dihydro-2 $\mathrm{H}$-pyridazine-3-one < 6-phenyl-2H-pyridazine-3one < 6-phenyl-2H-pyridazine-3-thione.

A few triazine based compounds studied as CIs of metals in acids were reported. It was shown that symmetrical 2,4,6-trisubstituted triazines with various structures weakly inhibited the corrosion of mild steel even in $0.1 \mathrm{M} \mathrm{HCl}\left(20^{\circ} \mathrm{C}\right)$ [76]. 1,3,5-Triazine 2,4,6triaminoethoxylate $(0.05 \%)$ is more efficient: according to electrochemical measurements, it provides $Z=91.3 \%$ in $1 \mathrm{M} \mathrm{HCl}\left(25^{\circ} \mathrm{C}\right.$ ) on carbon steel (composition, mass \%: $\mathrm{C} 0.3$; $\mathrm{Si}$ 0.02; Mn 0.03; P 0.04; Sn 0.045) [77]. An asymm-triazine derivative, the ceftriaxone antiobiotic $(10 \mathrm{mM})$ 


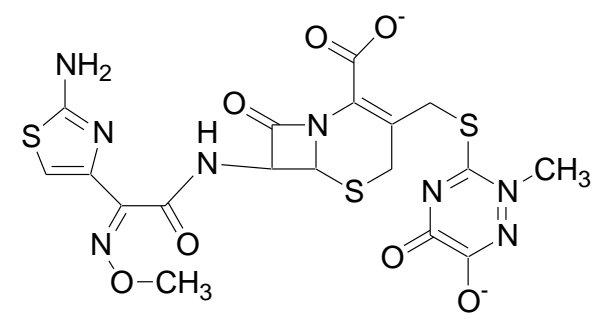

provides $Z=94.1 \%$ on mild steel in the same medium according to mass loss measurements, versus $80.3 \%$ for the amoxicillin antibiotic [78].

Voltammetric and mass loss measurements were used to study the corrosion of St3 (according to ISO 630-80, St3 steel is an analogue of $\mathrm{Fe} 360$ steels) in $\mathrm{HCl}$ and $\mathrm{H}_{3} \mathrm{PO}_{4}$ solutions $\left(t=25-95^{\circ} \mathrm{C}\right)$ in the presence of $N$-(2-chlorophenyl)-1,3,5-triazine-2,4-diamine derivatives. They considerably slow down the electrode reactions of St3 steel in $2 \mathrm{M} \mathrm{HCl}(t$ $=60^{\circ} \mathrm{C}$ ), but their efficiency in $2 \mathrm{M} \mathrm{H}_{3} \mathrm{PO}_{4}$ at the same temperature is low. $\mathrm{N}$-(2Chlorophenyl)-6-linoleyl-1,3,5-triazine-2,4-diamine is the most promising CI for steel. It hinders the corrosion of St3 in $2 \mathrm{M} \mathrm{HCl} 15-75$ fold at $t=25-80^{\circ} \mathrm{C}$. In this case, the coefficient of corrosion inhibition with this $\mathrm{CI}$ increases with a $t$ increase. Conversely, this CI poorly hinders corrosion in $2 \mathrm{M} \mathrm{H}_{3} \mathrm{PO}_{4}$ according to electrochemical studies [79].

The protective properties of hydrogenized triazine derivatives were also studied. It was shown that the protection of mild steel in $1 \mathrm{M} \mathrm{HCl}\left(27^{\circ} \mathrm{C}\right)$ with 6-R-4-amino-3-thioxo3,4-dihydro-1,2,4-triazin-5(2H)-ones improved in the $\mathrm{R}$ series: methyl < tert-butyl < benzyl. According to voltammetry and EIS data, the most efficient inhibitor of this series provided $Z>99 \%$ at $C_{\text {in }}=0.02 \%$ [80]. The same compounds with methyl and benzyl R were studied as corrosion inhibitors of aluminum in $1 \mathrm{M} \mathrm{HNO}_{3}$ (at room temperature), where $Z=93.3$ and $97.7 \%$ was reached at $C_{\text {in }}=0.01 \%$ according to EIS data [81].

Derivatives of trihydro-1,3,5-triazine were studied more thoroughly. For example, according to electrochemical studies, compounds with the composition

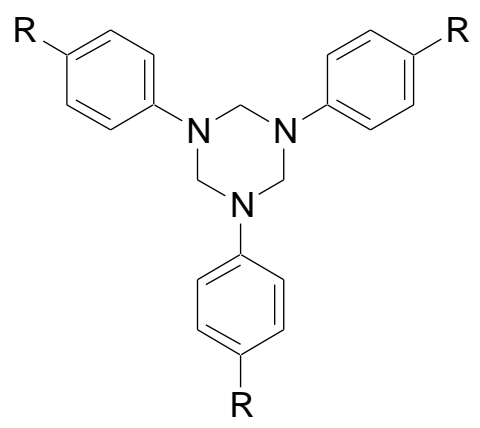

slowed down mild steel corrosion in $1 \mathrm{M} \mathrm{HCl}\left(35^{\circ} \mathrm{C}\right)$, where the protection increased in the $\mathrm{R}$ series: $\mathrm{NO}_{2}<\mathrm{H}<\mathrm{CH}_{3}<\mathrm{OCH}_{3}<\mathrm{NH}_{2}$. The $Z$ values of these CIs (0.03\%) were 84.8, 92.7, 93.7, 95.0 and 97.0\%, respectively [82, 83]. Surface active compounds with the composition shown below $(1 \mathrm{mM})$ are less efficient in the corrosion inhibition of CS37 carbon steel (composition, mass\%: C 0.11; Si 0.25; Mn 0.45; P 0.04; S 0.05) in $1 \mathrm{M} \mathrm{HCl}$ $\left(25^{\circ} \mathrm{C}\right)$. 


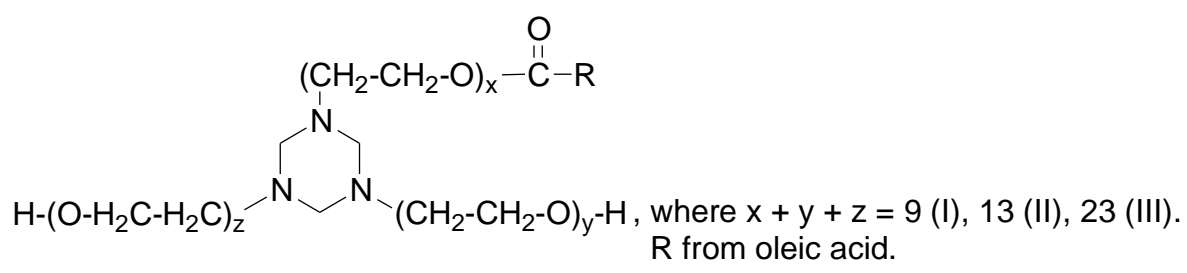

The $Z$ values of these compounds are 87.1 (I), 90.7 (II) and 93.1\% (III) [84]. It was shown that corrosion inhibition of mild steel in a $\mathrm{H}_{2} \mathrm{SO}_{4}$ solution with 1,3,5tribenzyltrihydro-1,3,5-triazine results from the adsorption of this CI on the metal and suppression of cathodic hydrogen evolution due to the creation of an adsorption potential jump and a change in the process rate, but not from surface blocking by the inhibitor [85, 86].

According to mass loss, voltammetry and EIS data, a hydrogenized derivative of tetrazine - 3,6-bis(2-methoxyphenyl)-1,2-dihydro-1,2,4,5-tetrazine - is an efficient CI of mild steel in $1 \mathrm{M} \mathrm{HCl}\left(30^{\circ} \mathrm{C}\right)$ but has poor efficiency in $0.5 \mathrm{M} \mathrm{H}_{2} \mathrm{SO}_{4}$ : at $C_{\text {in }}=0.1 \mathrm{~g} / \mathrm{l}$ it provides $Z<95.8 \%$ and $Z>68.2 \%$, respectively. According to voltammetry data, an increase in temperature of $1 \mathrm{M} \mathrm{HCl}$ from 25 to $60^{\circ} \mathrm{C}$ increases $Z$ from 94.5 to $96.4 \%$ [87].

Compounds whose structures involved a few simple nitrogen-containing sixmembered heterocycles at once were reported. 3,6-bis(3-Pyridyl)pyridazine $\left(C_{\mathrm{in}}=0.2-\right.$ $1.2 \mathrm{mM}$ ) can slow down the corrosion of $\mathrm{C} 35 \mathrm{E}$ carbon steel (composition, mass \%: $\mathrm{C} 0.37$; Si 0.23; Mn 0.68; S 0.016; Cr 0.077; Ti 0.011; Ni 0.059; Co 0.009; $\mathrm{Cu} 0.16$ ) in $1 \mathrm{M} \mathrm{HCl}$ $\left(30^{\circ} \mathrm{C}\right)$, giving $Z=87.4-92.8 \%$ [88]. According to voltammetry and EIS data, 2,4,6-tris(2pyridyl)-1,3,5-triazine poorly inhibits the corrosion of mild steel in $1 \mathrm{M} \mathrm{HCl}$ at room temperature $(Z<90 \%)$, being inferior to a trisubstituted tetrazole derivative, 2,3,5triphenyl-2H-tetrazolium chloride [89]. This triazine inhibits the corrosion of Sn, In and their alloy (5\% In) in the same medium. According to electrochemical data, the inhibition effect at $C_{\text {in }}=0.001 \mathrm{mM}$ decreases in the series: alloy $>\mathrm{In}>\mathrm{Sn}$, while at $C_{\text {in }}=1 \mathrm{mM}$, in the series $\mathrm{Sn}>\mathrm{In}>$ alloy [90]. The 1,3,5-triazine-2,4,6-triamine derivative containing a pyrimidine ring

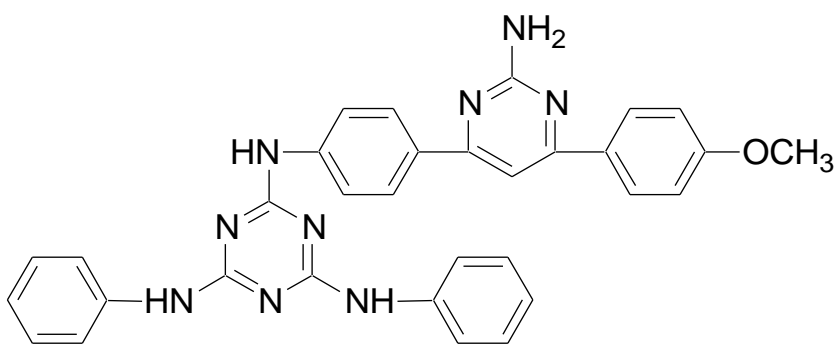

protects N80 steel (composition, mass\%: C 0.34-0.38; Si 0.20-0.35; Mn 1.45-1.7; P up to 0.02 ; $\mathrm{S}$ up to 0.015 ; $\mathrm{Cr}$ up to 0.15 ; $\mathrm{V} 0.11-0.16)$ in $15 \% \mathrm{HCl}\left(30^{\circ} \mathrm{C}\right)$, providing $Z=93.0-$ $94.6 \%$ at $C_{\text {in }}=0.015 \%$ according to gravimetry, voltammetry and EIS data [91]. A compound with a similar structure 


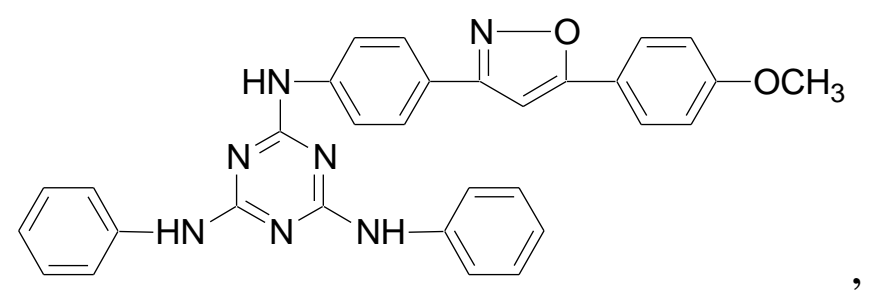

which contains a 1,2-oxazole ring instead of a pyrimidine one, is inferior in protective properties to the former compound.

\section{Complex systems}

Quinoline poorly inhibits steel corrosion on its own. Even at $C_{\text {in }}=0.1 \mathrm{M}$ on mild steel in $0.5 \mathrm{M} \mathrm{HCl}\left(30-40^{\circ} \mathrm{C}\right), Z \leq 88.7 \%$. 2-Methylquinoline and quinoline-2-carboxylic acid provide somewhat better protection under the same conditions $(Z \leq 91.4 \%$ and $Z \leq 94.2 \%$, respectively) [92]. The observed effect is in full agreement with the quantum-chemical calculations performed by the same researchers [93], according to which quinoline-2carboxylic acid should provide the maximum protection of steel in acid media. Low protective effects under similar conditions are provided by quinoline derivatives with small substituents: 8-hydroxyquinoline, 3-formyl-8-hydroxyquinoline [94], 2-chloro-6nitroquinoline-3-carbaldehyde [95], 2,6-dichloro-8-nitroquinoline-3-carbaldehyde [95], 2chloro-3-formylquinoline [96], and 3-formyl-2-chloroquinoline [97, 98]. It is interesting that modification of the latter compound by conversion to higher-molecular azomethines only worsens the steel protection [97]. Only the Schiff base obtained in the reaction of 3formyl-2-chloroquinoline with $p$-methylaniline protects steel with $Z>90 \%$ [98]. Azomethines with the composition

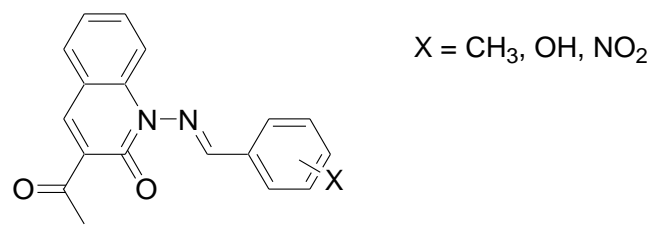

on $\mathrm{N} 80$ steel in $15 \% \mathrm{HCl}\left(35^{\circ} \mathrm{C}\right)$ are more interesting. According to EIS data, they provide $Z \geq 91.3 \%$. However, according to mass loss studies, their efficiency decreases strongly with a temperature increase [99]. Sulfur-containing azomethines [100-102]

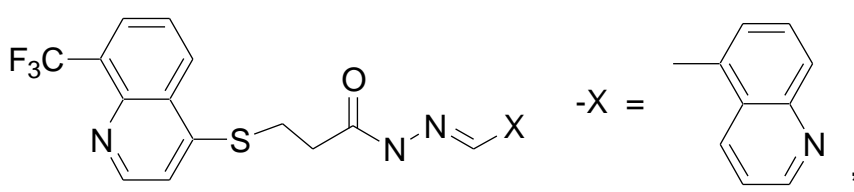

(I)

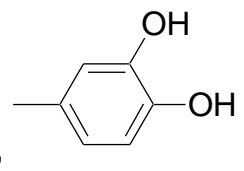

(II)

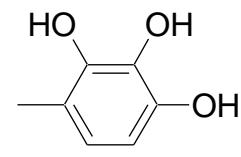

(III)

containing the hydrophobic $\mathrm{CF}_{3}$ group were studied as $\mathrm{CIs}$ in $\mathrm{HCl}$. For example, according to gravimetry data, $0.05 \%$ of compound (I) in $1 \mathrm{M} \mathrm{HCl}$ solution $\left(30^{\circ} \mathrm{C}\right)$ strongly inhibits 
the corrosion of mild steel $(Z=93.6 \%)$, but the protective effect of the CI decreases with an increase in temperature to $60^{\circ} \mathrm{C}(Z=84.4 \%)$ or $C_{\mathrm{HCl}}$ to $2 \mathrm{M}(Z=91.6 \%)$ [100].

According to mass loss, voltammetry and EIS data, 6-benzylquinoline and 6(quinolin-6-ylmethyl)benzene-1,2,3,4,5-pentasulfonic acid inhibit the corrosion of mild steel in $1 \mathrm{M} \mathrm{HCl}\left(25^{\circ} \mathrm{C}\right)$, providing $Z=94.7$ and $97.2 \%$, respectively, at $C_{\text {in }}=1.0 \mathrm{mM}$ [103].

4-Substituted 2-amino-7-hydroxy-1,4-dihydroquinoline-3-carbonitriles are strong corrosion inhibitors of mild steel in $1 \mathrm{M} \mathrm{HCl}\left(35^{\circ} \mathrm{C}\right)$. Their efficiency increases in the series: 2-amino-7-hydroxy-4-phenyl-1,4-dihydroquinoline-3-carbonitrile $<2$-amino-7hydroxy-4-( $p$-tolyl)-1,4-dihydroquinoline-3-carbonitrile $\quad<\quad$ 2-amino-7-hydroxy-4-(4methoxyphenyl)-1,4-dihydroquinoline-3-carbonitrile $<$ 2-amino-4-(4-(dimethylamino)phenyl)-7-hydroxy-1,4-dihydroquinoline-3-carbonitrile [104].

In "cold" $\mathrm{HCl}$ solutions, the corrosion of carbon steel is efficiently hindered by some antibiotics, viz., ciprofloxacin (I), norfloxacin (II), ofloxacin (III) [105], and gatifloxacin (IV) [106]:

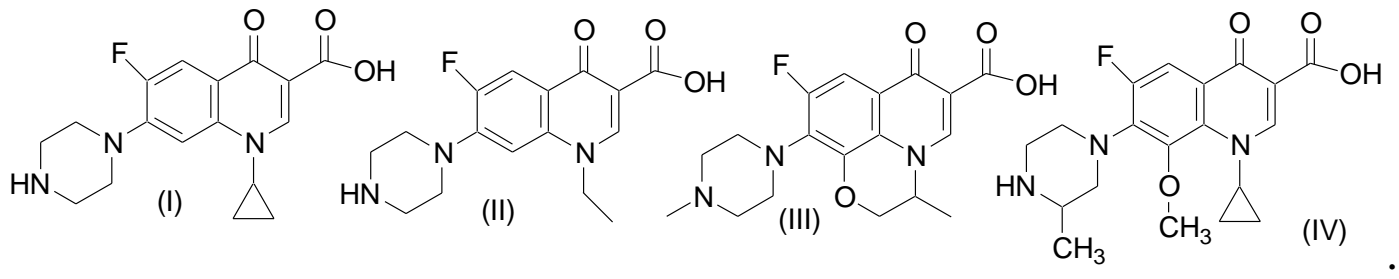

It has been shown for gatifloxacin as an example that that a temperature increase decreases the inhibitory properties [106].

Quaternization is an important method to increase the protective efficiency of quinolines. For example, according to EIS data, $N$-benzylquinolinium chloride $(37 \mathrm{mM})$ provides $Z=94.6 \%$ in $15 \% \mathrm{HCl}$ for $\mathrm{N} 80$ steel at $20^{\circ} \mathrm{C}$, but already at $90^{\circ} \mathrm{C}, Z=79.4 \%$ according to mass loss data [107].

The studies on quinoline derivatives as CIs of metals in $\mathrm{H}_{2} \mathrm{SO}_{4}$ have not been systematized and are fragmentary. The substituted quinoline with the structure

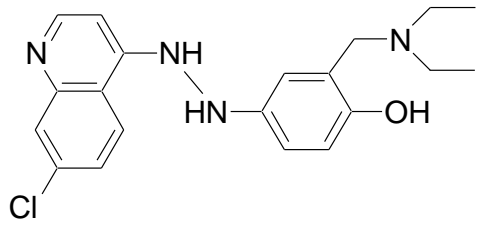

poorly inhibits the corrosion of mild steel in $0.5 \mathrm{M} \mathrm{H}_{2} \mathrm{SO}_{4}$ even at $C_{\text {in }}=0.01 \mathrm{M}(\mathrm{Z}=$ 79.4\%) [108]. Good protection of steel in $\mathrm{H}_{2} \mathrm{SO}_{4}$ can be reached using CIs such as substituted quinolinium iodides or bromides [109], which is a result of synergistic action of the cationic surfactant and halide ions, as well as sulfur-containing quinoline derivatives [102]. 
Of isoquinoline derivatives, 1-methylisoquinoline has been studied. Like lowmolecular quinoline derivatives, it poorly protects mild steel in $\mathrm{HCl}$ [110].

Acridine is known as a steel corrosion inhibitor in $\mathrm{HCl}$ and $\mathrm{H}_{2} \mathrm{SO}_{4}$ solutions, but the protective effects of this compound are low. Higher protection is provided by its substituted derivatives and acridinium salts [45]. It is noted that acridine can be used to protect aluminum and its alloys with copper [45] and zinc [111] in hydrochloric acid. For example, $Z=80-98 \%$ for an alloy containing $4.5-6.5 \%$ zinc.

Data on the protection of metals in acid media with quinoxalines are more abundant. Both quinoxaline itself and its derivatives containing the $\mathrm{Cl}, \mathrm{SH}$ and $\mathrm{C}_{6} \mathrm{H}_{4}-\mathrm{OH}$ groups at position 2 poorly inhibit the corrosion of mild steel in $1 \mathrm{M} \mathrm{HCl}\left(25^{\circ} \mathrm{C}\right)$ at $C_{\text {in }}=1 \mathrm{mM}: Z=$ 69.9, 72.6, 79.3 and $85.0 \%$, respectively [112]. The authors [112] believe that this result correlates rather well with the binding energies of these compounds $(321,344,370$ and 523 $\mathrm{kJ} / \mathrm{mol}$ ) with $\mathrm{Fe}(110)$ surface calculated by molecular dynamics simulations. Higher protective effects are demonstrated by quinoxalines with bulky substituents:
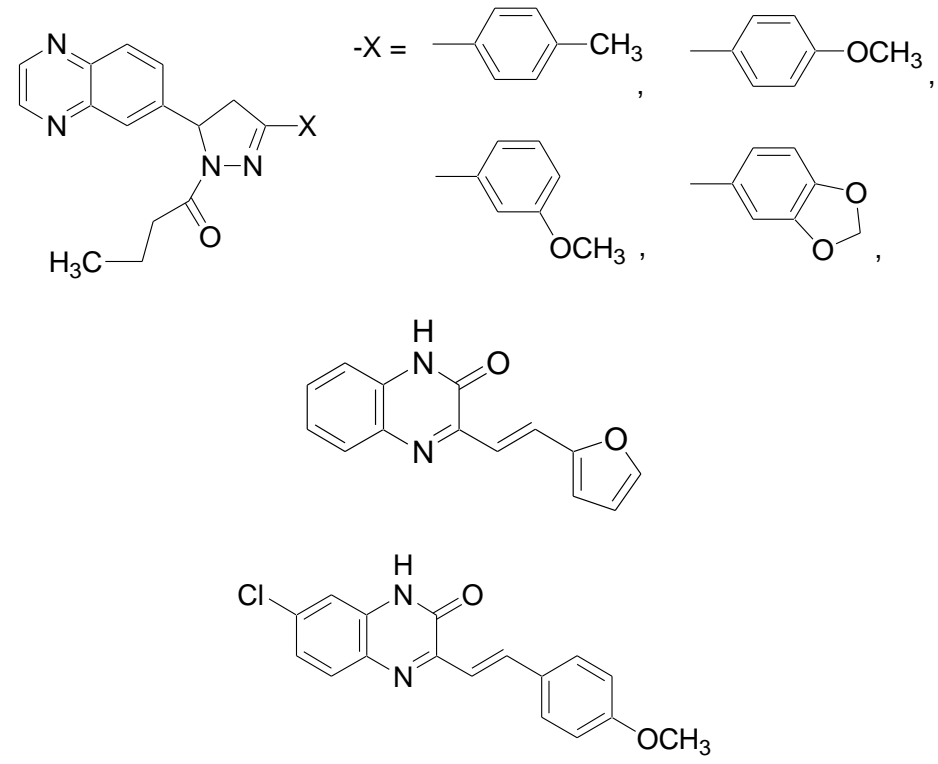

$[115,116]$.

According to corrosion studies, 3-methyl-2-phenylquinoxaline and 2,3diphenylquinoxaline $(1 \mathrm{mM})$ considerably inhibit the corrosion of mild steel in $1 \mathrm{M} \mathrm{H}_{2} \mathrm{SO}_{4}$ at $30^{\circ} \mathrm{C}(Z=95.1$ and $96.4 \%)$, but their more hydrophilic analogues, 3-methyl-2(2'hydroxyphenyl)quinoxaline and 3-phenyl-2(2'-hydroxyphenyl)quinoxaline, have low efficiency $(Z=80.3$ and $88.9 \%)$ [117].

Among quinoxaline derivatives, 3-methyl-1-prop-2-ynylquinoxaline-2(1H)-thione should be distinguished:

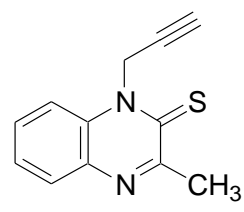


Its protective effect on mild steel in $1 \mathrm{M} \mathrm{HCl}$ is preserved fairly well in the $t$ range of $35-80^{\circ} \mathrm{C}$. The presence of $1 \mathrm{mM}$ of this $\mathrm{CI}$ in the solution hinders corrosion at least 20 fold. This kind of dependence of the protective effect on $t$ is not typical of $N$-containing six-membered heterocyclic compounds and is due to the propargyl moiety present in the molecule. It is known $[13,14,119]$ that organic compounds containing a propargyl moiety protect steel in hydrochloric acid solutions in a broad range of temperatures up to $100^{\circ} \mathrm{C}$. The presence of a $\mathrm{C} \equiv \mathrm{C}$ unsaturated bond in these compounds predetermines their adsorption-polymerization mechanism of action [120-122], according to which inhibitor molecules are first adsorbed on a metal surface and then a protective film is formed by polymerization processes on the surface. An increase in $t$ accelerates the formation of the protective film and thus enhances the protective effects. A similar action mechanism is typical of compounds with conjugated unsaturated $\mathrm{C}=\mathrm{C}$ and $\mathrm{C}=\mathrm{O}$ bonds [123]. Compounds containing such groups often show protective effects in heated $\mathrm{HCl}$ solutions. It is logical to assume that a similar protective mechanism should work in the case of 3-methyl-1-prop2-ynylquinoxaline-2(1H)-thione.

Substituted 1,4-dihydroquinoxalines (1,4-dihydroquinoxaline-2,3-dione $\left(Z_{0.5 \mathrm{mM}}=\right.$ 87\%) [124], (E)-3-(4-methoxystyryl)-7-methylquinoxalin-2(1H)-one $\left(Z_{1 \mathrm{mM}}=90 \%\right)$ [125], 2-(4-methylphenyl)-1,4-dihydroquinoxaline $\left(Z_{1 \mathrm{mM}}=91 \%\right)$ [126], and 2-[3-(2-oxo-2phenylethylidene)-1,4-dihydroquinoxaline- $2(1 H)$-ylidene]-1-phenylethanone $\left(Z_{0.1 \mathrm{mM}}=81 \%\right)$ [127]) inhibit the corrosion of mild steel in $1 \mathrm{M} \mathrm{HCl}$ at nearly room temperatures. Under the same conditions, mild steel is protected in $1 \mathrm{M} \mathrm{H}_{2} \mathrm{SO}_{4}$ by the compounds:

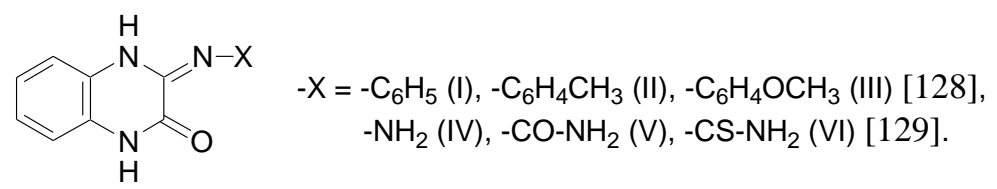

Strong inhibitory properties are shown by compounds I-III, VI.
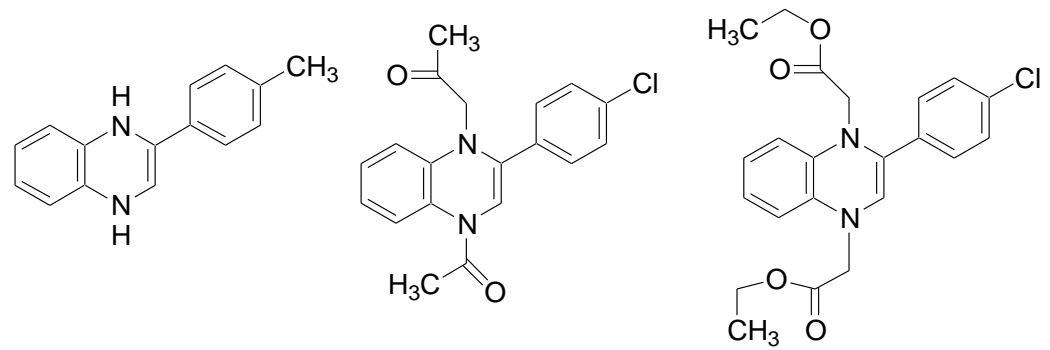

Some of the compounds $(1 \mathrm{mM})$ inhibit copper corrosion in $2 \mathrm{M} \mathrm{HNO}_{3}\left(30^{\circ} \mathrm{C}\right): Z=$ $82.8,91.8$ and $97.0 \%$ [130].

The inhibitive action of CIs containing two fused six-membered rings with three and four nitrogen heteroatoms was reported. 7-Methoxypyrido[2,3- $d]$ pyrimidin-4-amine and 4amino-7-methoxypyrido[2,3-d]pyrimidin-2(1H)-one 


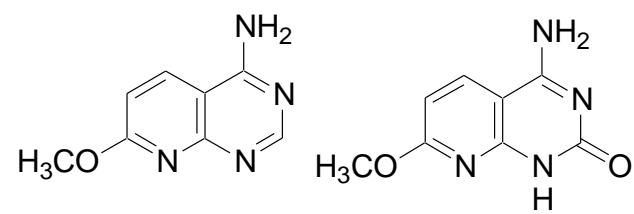

at $0.02 \%$ concentration in $15 \% \mathrm{HCl}\left(60^{\circ} \mathrm{C}\right)$ provide $Z$ no. worse than $92.4 \%$ [131], though their protective action decreases with an increase in temperature. Under the same conditions, 5-styryl-2,7-dithioxo-2,3,5,6,7,8-hexahydropyrimido[4,5- $d]$ pyrimidin-4(1H)one and 5-(2-hydroxyphenyl)-2,7-dithioxo-2,3,5,6,7,8-hexahydropyrimido[4,5- $d$ ]pyrimidin$4(1 H)$ one

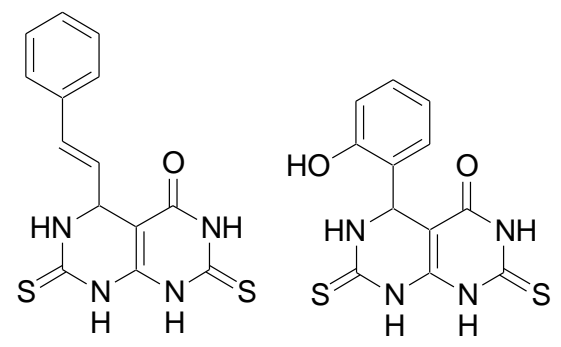

inhibit the corrosion of N80 steel much worse, though they contain sulfur atoms [132].

Phenazine even at $C_{\mathrm{in}}=0.1 \mathrm{M}$ weakly inhibits the corrosion of mild steel in $\mathrm{H}_{2} \mathrm{SO}_{4}$ at $30^{\circ} \mathrm{C}(Z=80 \%)$, being inferior in this respect to 1,12-phenathroline, phenothiazine, and phenoxazine [133]. A higher protective effect is shown by 2,3-diphenylbenzoquinoxaline that provides $Z=99 \%$ on mild steel in $0.5 \mathrm{M} \mathrm{H}_{2} \mathrm{SO}_{4}\left(30^{\circ} \mathrm{C}\right)$ at $C_{\mathrm{in}}=10 \mu \mathrm{M}$ [134]. Under the same conditions, the $Z$ value provided by acenaphtho[1,2- $b$ ]quinoxaline

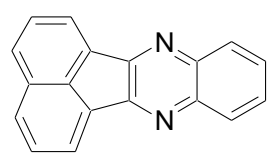

is as low as $80 \%$ [135], while $Z=90 \%$ in the presence of this compound in $1 \mathrm{M} \mathrm{H}_{2} \mathrm{SO}_{4}$ $\left(30^{\circ} \mathrm{C}\right)$ is reached at $C_{\text {in }}=10 \mathrm{mM}[136]$.

It should be noted in this review that we deliberately did not cover organic compounds containing both six- and five-membered nitrogen-containing organic rings, including fused ones. To our understanding, the inhibitory action of such compounds is largely determined by the properties of five-membered heterocycles $[5,13]$ that require a separate consideration. The same corresponds to compounds incorporating five-membered rings with $\mathrm{O}$ and $\mathrm{S}$ heteroatoms.

Thus, six-membered nitrogen-containing heterocyclic compounds can inhibit the corrosion of carbon steels in $\mathrm{HCl}$ solutions. As a rule, their inhibitive action is improved by incorporation of bulky R or mercapto groups in their molecules. Conversely, in $\mathrm{HClO}_{4}$, $\mathrm{H}_{2} \mathrm{SO}_{4}$, and $\mathrm{H}_{3} \mathrm{PO}_{4}$ solutions, these CIs often have low inhibitory effects, except for the cases where mercapto derivatives of heterocycles are used. It often happens that an increase in the temperature of an acid solution at least to $60^{\circ} \mathrm{C}$ decreases the protective action of these CIs considerably. Apart from inhibition of mild steels, they can be used to 
inhibit the corrosion of stainless steels and non-ferrous metals $(\mathrm{Al}, \mathrm{Cu}, \mathrm{Sn}, \mathrm{Zn}$ and their alloys) in $\mathrm{HCl}$ and $\mathrm{HNO}_{3}$ solutions. Analysis of literature shows that individual sixmembered nitrogen-containing heterocycles are rarely used in acids as industrial CIs of metals, since it is important in these cases to provide efficient metal protection at $t \geq 60^{\circ} \mathrm{C}$.

\section{Specifics of the action mechanism of nitrogen-containing six-membered heterocyclic CIs of metals in acid media}

Important information about the mechanism of $\mathrm{CI}$ action can be obtained by analyzing the processes of $\mathrm{CI}$ adsorption on metals. As a rule, the stronger the adsorption of a CI on a metal, the higher its protective effects that can be expected. The best protective effects are provided by CIs that chemically interact with a metal surface. It is believed that if the standard free adsorption energy $\left(-\Delta G_{\mathrm{a}}^{0}\right)$ is less than $20 \mathrm{~kJ} / \mathrm{mol}$, then it is of physical nature. Only if $\left(-\Delta G_{\mathrm{a}}^{0}\right) \geq 40 \mathrm{~kJ} / \mathrm{mol}$, one can state with high probability that the inhibitor is chemisorbed. Unfortunately, the literature sources that we studied contain data on the adsorption of nitrogen-containing six-membered heterocyclic compounds on metals from acid solutions (Tables 1 and 2) calculated only from the results of corrosion studies on these metals based on the mass loss of specimens, which is a rough approximation that gives considerable errors. The majority of researchers adhere to the opinion that adsorption of such CIs on metals is most adequately described by the Langmuir isotherm, which they choose formally from the list of existing isotherms. The reported data indicate the high adsorption activity of six-membered nitrogen-containing heterocycles on steels and non-ferrous metals, but in most cases the observed $\left(-\Delta G_{\mathrm{a}}^{0}\right)$ values are insufficient for an unambiguous conclusion that they are chemisorbed on a metal surface. Only for some sulfur-containing heterocyclic compounds or heterocycles with bulky $\mathrm{R},\left(-\Delta G_{\mathrm{a}}^{0}\right) \geq 40 \mathrm{~kJ} / \mathrm{mol}$, which is evidence in favor of chemisorption. Comparison of data on adsorption of nitrogencontaining six-membered heterocyclic CIs with the results of corrosion studies allows the conclusion to be made that the nature of interaction of the majority of these compounds with metals is predominantly of physical nature, since such compounds are generally lowefficiency CIs or easily lose the protective effect as the temperature increases.

As a result of adsorption interaction of these compounds with metal surfaces, they decrease the double electric layer capacity, strongly hinder both electrode reactions and increase the polarization resistance. These factors ultimately determine the protective effect of these CIs. The literature that we analyzed reveals no. information that six-membered nitrogen-containing heterocyclic compounds form polymolecular protective layers on the metal surface that are characteristic of triazoles, i.e., another group of heterocycles. As we have shown previously [137-139], the fact that triazoles form such layers on steel surface allows the highest protective effects to be reached. The fact that triazoles form protective layers on metal surfaces makes it possible to use them for the protection of mild and chromium-nickel steels even under high-temperature acid corrosion conditions [140-142]. 
Table 2. Free adsorption energies of nitrogen-containing six-membered heterocyclic compounds on metals from acid media.

\begin{tabular}{|c|c|c|c|c|}
\hline Inhibitor & Type of metal & $\begin{array}{l}\text { Type of } \\
\text { corrosive } \\
\text { medium }\end{array}$ & $\begin{array}{c}\text { Standard } \\
\text { adsorption free } \\
\text { energy }\left(-\Delta G_{\text {ads }}\right)^{*} \\
\mathbf{k J} / \mathbf{m o l}\end{array}$ & Ref. \\
\hline \multicolumn{5}{|c|}{ Pyridines } \\
\hline 2-(4-Pyridyl)-benzimidazole & Mild steel & $\begin{array}{l}1.0 \mathrm{M} \mathrm{HCl} \\
\left(25^{\circ} \mathrm{C}\right)\end{array}$ & 32.4 & 29 \\
\hline $\begin{array}{l}\text { Pyridine-2-thiol and 2-pyridyl } \\
\text { disulfide }\end{array}$ & Mild steel & $\begin{array}{l}0.1 \mathrm{M} \mathrm{HCl} \\
\left(25^{\circ} \mathrm{C}\right)\end{array}$ & $34.3,37.2$ & 33 \\
\hline \multirow[b]{2}{*}{$\begin{array}{l}o, m, p \text {-Pyridinecarboxaldehyde } \\
\text { thiosemicarbazones }\end{array}$} & Mild steel & $1 \mathrm{M} \mathrm{HCl}\left(30^{\circ} \mathrm{C}\right)$ & $37.2,35.8,33.1$ & $\begin{array}{l}34, \\
35\end{array}$ \\
\hline & $\begin{array}{l}\text { Aluminum } \\
\text { (Puratronic, } \\
99.999 \%)\end{array}$ & $\begin{array}{l}1.0 \mathrm{M} \mathrm{HNO}_{3} \\
\quad\left(25^{\circ} \mathrm{C}\right)\end{array}$ & $27.7,28.7,27.8$ & 36 \\
\hline $\begin{array}{l}\text { 4-Pyridinecarboxaldehyde-4- } \\
\text { phenylthiosemicarbazide; } \\
\text { 3-pyridinecarboxaldehyde-4- } \\
\text { phenylthiosemicarbazide }\end{array}$ & Mild steel & $\begin{array}{c}1 \mathrm{HCl}(30- \\
\left.50^{\circ} \mathrm{C}\right)\end{array}$ & $\begin{array}{l}41.2-41.6,43.1- \\
48.6\end{array}$ & 37 \\
\hline $\begin{array}{c}\text { 2,5-bis }(o, m, p \text {-Pyridyl)-1,3,4- } \\
\text { thiadiazoles }\end{array}$ & Mild steel & $\begin{array}{c}1 \mathrm{M} \mathrm{HCl}, 0.5 \mathrm{M} \\
\mathrm{H}_{2} \mathrm{SO}_{4}, 1 \mathrm{M} \\
\mathrm{HClO}_{4}\left(30^{\circ} \mathrm{C}\right)\end{array}$ & $\begin{array}{c}38.4,40.4,34.9 \\
(\mathrm{HCl}), 35.4,36.4 \\
32.7\left(\mathrm{H}_{2} \mathrm{SO}_{4}\right), \\
34.4\left(\mathrm{HClO}_{4}, m_{-}\right. \\
\text {isomer })\end{array}$ & 38 \\
\hline 2-Pyridinecarbonitrile & Mild steel & $\begin{array}{l}0.1 \mathrm{M} \mathrm{HCl} \\
\left(25^{\circ} \mathrm{C}\right)\end{array}$ & 34.9 & 40 \\
\hline $\begin{array}{c}\text { 2-Amino-6-methoxy-4- } \\
\text { phenylpyridine-3,5-dicarbonitrile; } \\
\text { 2-Amino-6-methoxy-4-(4- } \\
\text { methylphenyl)pyridine-3,5- } \\
\text { dicarbonitrile; } \\
\text { 2-Amino-6-methoxy-4-(4- } \\
\text { methoxylphenyl)pyridine-3,5- } \\
\text { dicarbonitrile }\end{array}$ & Mild steel & $\begin{array}{c}1 \mathrm{M} \mathrm{HCl}(35- \\
\left.65^{\circ} \mathrm{C}\right)\end{array}$ & $\begin{array}{l}33.2-37.4 ; 32.6- \\
35.8 ; 31.8-33.9\end{array}$ & 42 \\
\hline $\begin{array}{l}\text { 2-Amino-4-(4-methoxyphenyl)-6- } \\
\text { phenylnicotinonitrile; } \\
\text { 2-Amino-6-(2,4-dihydroxyphenyl)- } \\
\text { 4-(4-methoxyphenyl)nicotinonitrile }\end{array}$ & N80 steel & $15 \% \mathrm{HCl}\left(35^{\circ} \mathrm{C}\right)$ & $\begin{array}{l}30.6 \\
29.9\end{array}$ & 43 \\
\hline
\end{tabular}




\begin{tabular}{|c|c|c|c|c|}
\hline Inhibitor & Type of metal & $\begin{array}{l}\text { Type of } \\
\text { corrosive } \\
\text { medium }\end{array}$ & $\begin{array}{c}\text { Standard } \\
\text { adsorption free } \\
\text { energy }\left(-\Delta G_{\text {ads }}\right)^{*}, \\
\mathbf{k J} / \mathbf{m o l}\end{array}$ & Ref. \\
\hline $\begin{array}{c}\text { 4-[((4-(bis(pyridin-2- } \\
\text { ylmethyl)amino)phenyl)imino)- } \\
\text { methyl]- } N, N \text {-diethylaniline }\end{array}$ & Q235 mild steel & $\begin{array}{c}1 \mathrm{M} \mathrm{HCl}(35- \\
\left.55^{\circ} \mathrm{C}\right)\end{array}$ & $31.4-32.7$ & 44 \\
\hline $\begin{array}{c}\text { 1-Methyl-4[4'(-X)-styryl]- } \\
\text { pyridinium iodides (X: } \mathrm{H}, \mathrm{Cl}, \mathrm{OH})\end{array}$ & $\mathrm{Al}-\mathrm{Cu}$ alloy & $\begin{array}{l}0.5 \mathrm{M} \mathrm{HCl} \\
\left(30^{\circ} \mathrm{C}\right)\end{array}$ & $36.1,36.8,37.4$ & 46 \\
\hline \multicolumn{5}{|c|}{ Pyrimidines } \\
\hline 4,6-Diamino-2-pyrimidinethiol & Mild steel & $\begin{array}{l}0.1 \mathrm{M} \mathrm{HCl} \\
\left(25^{\circ} \mathrm{C}\right)\end{array}$ & 34.0 & 49 \\
\hline 2-Amino-4,6-dihydroxypyrimidine & Carbon steel & $\begin{array}{c}1 \mathrm{M} \mathrm{HCl} \\
\left(20-50^{\circ} \mathrm{C}\right)\end{array}$ & $20 \pm 2$ & 50 \\
\hline $\begin{array}{l}\text { 2-Aminopyrimidine and } 2,4- \\
\text { diaminopyrimidine }\end{array}$ & Cold rolled steel & $\begin{array}{l}0.5 \mathrm{M} \mathrm{H}_{2} \mathrm{SO}_{4} \\
\quad\left(20^{\circ} \mathrm{C}\right)\end{array}$ & $23.5,24.9$ & 51 \\
\hline $\begin{array}{l}\text { 4-Phenylpyrimidine and 5- } \\
\text { phenylpyrimidine }\end{array}$ & Cold rolled steel & $\mathrm{HCl}\left(30^{\circ} \mathrm{C}\right)$ & $29.2,28.5$ & 55 \\
\hline 2-Mercaptopyrimidine & Cold rolled steel & $\begin{array}{l}0.1 \mathrm{M} \mathrm{HNO}_{3} \\
\left(20-50^{\circ} \mathrm{C}\right)\end{array}$ & $38.2-41.0$ & 58 \\
\hline bis-Pyrimidin-2-thiol derivative & Mild steel & $\begin{array}{l}1 \mathrm{M} \mathrm{H}_{2} \mathrm{SO}_{4} \\
\text { (room } \\
\text { temperature) }\end{array}$ & 40.5 & 59 \\
\hline $\begin{array}{l}\text { 5-Acetyl-6-methyl-4-(4- } \\
\text { nitrophenyl)-3,4-dihydropyrimidin- } \\
2(1 H) \text {-one, 5-acetyl-6-methyl-4-(3- } \\
\text { nitrophenyl)-3,4-dihydropyrimidin- } \\
2(1 H) \text {-one and 5-acetyl-6-methyl-4- } \\
\text { phenyl-3,4-dihydropyrimidin- } \\
\text { 2(1H)-one }\end{array}$ & Mild steel & $\begin{array}{c}1 \mathrm{M} \mathrm{HCl}(30- \\
\left.60^{\circ} \mathrm{C}\right)\end{array}$ & $\begin{array}{l}39.1-39.9,40.1- \\
42.1,45.2-47.9\end{array}$ & 60 \\
\hline $\begin{array}{c}\text { 5-(((4-nitrophenyl)amino)- } \\
\text { methylene)pyrimidine-2,4,6- } \\
(1 H, 3 H, 5 H)-\text { trione; } \\
\text { 5-((phenylamino)methylene)- } \\
\text { pyrimidine-2,4,6-(1H,3H,5H)- } \\
\text { trione; } \\
\text { 5-(((4-hydroxyphenyl)amino)- } \\
\text { methylene)pyrimidine-2,4,6- } \\
\text { (1H,3H,5H)-trione; } \\
\text { 5-(((2,4-dihydroxyphenyl)amino)- } \\
\text { methylene)pyrimidine-2,4,6- } \\
(1 H, 3 H, 5 H) \text {-trione }\end{array}$ & Mild steel & $\begin{array}{c}1 \mathrm{M} \mathrm{HCl}(35- \\
\left.65^{\circ} \mathrm{C}\right)\end{array}$ & $\begin{array}{c}32.2-34.0 ; 32.6- \\
34.6 ; 32.9-35.5 ; \\
33.7-37.3 \\
\text { (Temkin } \\
\text { adsorption } \\
\text { isotherms) }\end{array}$ & 63 \\
\hline
\end{tabular}




\begin{tabular}{|c|c|c|c|c|}
\hline Inhibitor & Type of metal & $\begin{array}{l}\text { Type of } \\
\text { corrosive } \\
\text { medium }\end{array}$ & $\begin{array}{c}\text { Standard } \\
\text { adsorption free } \\
\text { energy }\left(-\Delta G_{\text {ads }}\right)^{*}, \\
\mathbf{k J} / \mathbf{m o l}\end{array}$ & Ref. \\
\hline \multicolumn{5}{|c|}{ Pyridazines } \\
\hline $\begin{array}{l}\text { 5-Benzyl-6-methylpyridazine-3- } \\
\text { thione }\end{array}$ & $\begin{array}{l}\text { Pure iron }(99.5 \%, \\
\text { from Good } \\
\text { Fellow, } \\
\text { Cambridge, UK) }\end{array}$ & $\begin{array}{c}1 \mathrm{M} \mathrm{HCl}(25- \\
\left.80^{\circ} \mathrm{C}\right)\end{array}$ & $\begin{array}{l}48 \text { (Frumkin } \\
\text { isotherm } \\
\text { adsorption) }\end{array}$ & 67 \\
\hline $\begin{array}{c}\text { Ethyl(6-oxo-3-phenylpyridazin- } \\
1(6 H) \text {-yl)acetate and ethyl(3- } \\
\text { phenyl-6-thioxopyridazin-1(6H)- } \\
\text { yl)acetate }\end{array}$ & C38 Mild Steel & $1 \mathrm{M} \mathrm{HCl}\left(30^{\circ} \mathrm{C}\right)$ & 39.5 и 39.5 & 70 \\
\hline 6-Phenyl-2H-pyridazine-3-thione & Mild steel & $\begin{array}{c}1 \mathrm{M} \mathrm{HCl}(35- \\
\left.65^{\circ} \mathrm{C}\right)\end{array}$ & 40.1 & 75 \\
\hline \multicolumn{5}{|c|}{ Triazines } \\
\hline Ceftriaxone & Q235 Mild steel & $1 \mathrm{M} \mathrm{HCl}\left(25^{\circ} \mathrm{C}\right)$ & 45.6 & 78 \\
\hline 2,4,6-tris(2-Pyridyl)-1,3,5-triazine & Tin & $0.5 \mathrm{M} \mathrm{HCl}$ & $\begin{array}{l}73.5 \text { (Frumkin } \\
\text { isotherm } \\
\text { adsorption) }\end{array}$ & 90 \\
\hline $\begin{array}{l}\text { 1,3,5-Triazine-2,4,6-triamine } \\
\text { derivatives }\end{array}$ & N80 steel & $\begin{array}{c}15 \% \mathrm{HCl}(30- \\
\left.60^{\circ} \mathrm{C}\right)\end{array}$ & $38.6-41.6$ & 91 \\
\hline \multicolumn{5}{|c|}{ Quinolines and related structures } \\
\hline $\begin{array}{l}\text { Quinoline, 2-methylquinoline, } \\
\text { quinoline-2-carboxylic acid }\end{array}$ & Mild steel & $\begin{array}{l}0.5 \mathrm{M} \mathrm{HCl} \\
\quad\left(25^{\circ} \mathrm{C}\right)\end{array}$ & $\begin{array}{c}23.5,27.5 \\
37.4\end{array}$ & 92 \\
\hline $\begin{array}{l}\text { 8-Hydroxyquinoline and 3-formyl- } \\
\text { 8-hydroxyquinoline }\end{array}$ & Mild steel & $\begin{array}{c}1 \mathrm{M} \mathrm{HCl}(30- \\
\left.60^{\circ} \mathrm{C}\right)\end{array}$ & $\begin{array}{c}\text { 9.8-11.0, 11.9- } \\
13.2\end{array}$ & 94 \\
\hline $\begin{array}{l}\text { 2,6-Dichloroquinoline-3- } \\
\text { carbaldehyde; } \\
\text { 2-chloro-6-nitroquinoline-3- } \\
\text { carbaldehyde; } \\
\text { 2,6-dichloro-8-nitroquinoline-3- } \\
\text { carbaldehyde }\end{array}$ & Mild steel & $1 \mathrm{M} \mathrm{HCl}\left(30^{\circ} \mathrm{C}\right)$ & $36,35,34$ & 95 \\
\hline 2-Chloro-3-formylquinoline & Mild steel & $\begin{array}{c}1 \mathrm{M} \mathrm{HCl}(30- \\
\left.60^{\circ} \mathrm{C}\right)\end{array}$ & $\begin{array}{l}27.9-33.2 \\
\text { (Freundlich } \\
\text { adsorption } \\
\text { isotherm) }\end{array}$ & 96 \\
\hline
\end{tabular}




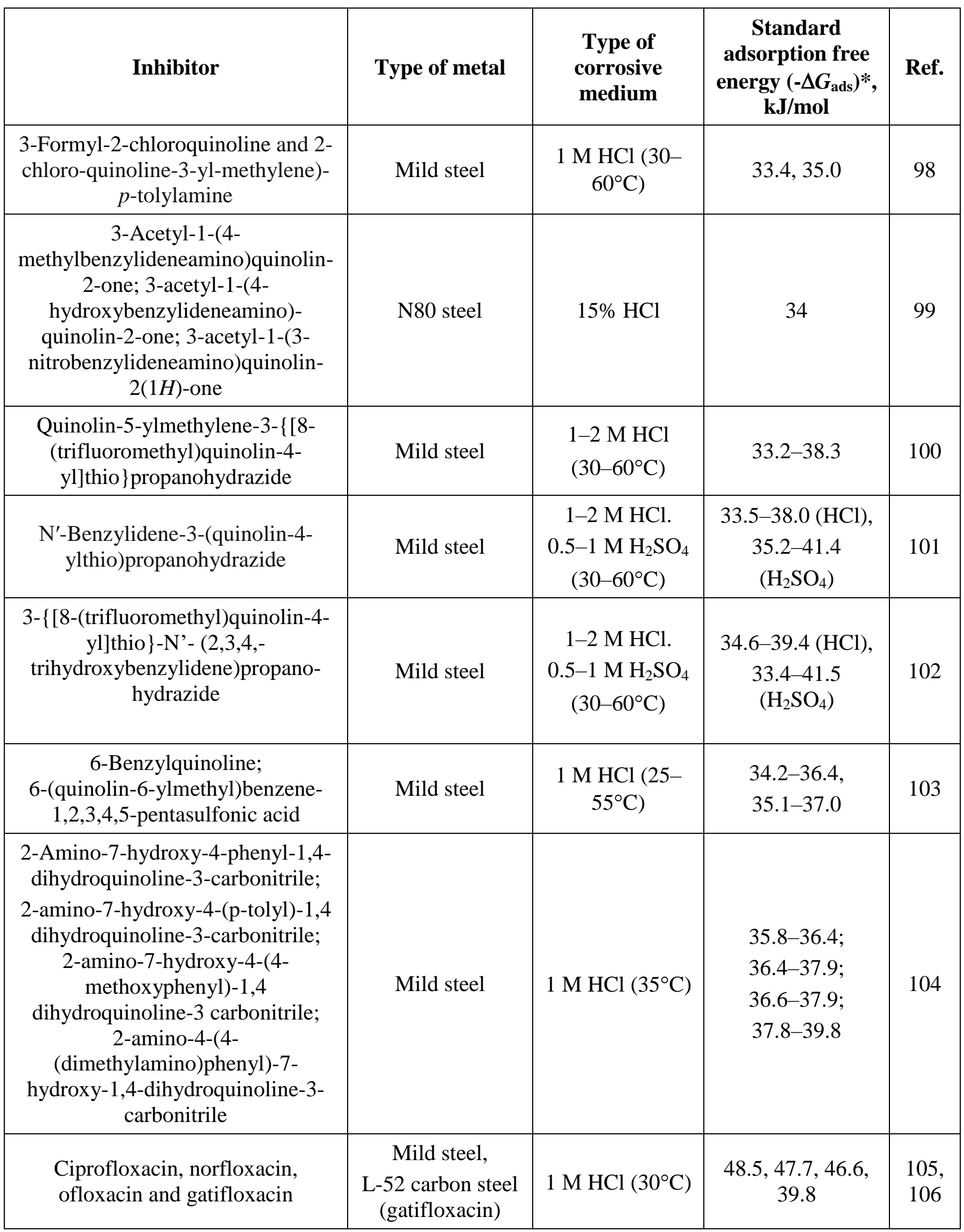




\begin{tabular}{|c|c|c|c|c|}
\hline Inhibitor & Type of metal & $\begin{array}{l}\text { Type of } \\
\text { corrosive } \\
\text { medium }\end{array}$ & $\begin{array}{c}\text { Standard } \\
\text { adsorption free } \\
\text { energy }\left(-\Delta G_{\text {ads }}\right) * \\
\mathbf{k J} / \mathbf{m o l}\end{array}$ & Ref. \\
\hline N-Benzylquinolinium chloride & N80 steel & $15 \% \mathrm{HCl}\left(90^{\circ} \mathrm{C}\right)$ & 30.3 & 107 \\
\hline 1-Substituted quinolin-1-ium iodide & Mild steel & $\begin{array}{l}0.5 \mathrm{M} \mathrm{H}_{2} \mathrm{SO}_{4} \\
\left(25-60^{\circ} \mathrm{C}\right)\end{array}$ & $33.4-41.6$ & 109 \\
\hline \multicolumn{5}{|c|}{ Quinoxalines and related structures } \\
\hline $\begin{array}{c}\text { 3-Methyl-1-prop-2- } \\
\text { ynylquinoxaline-2(1H)-thione }\end{array}$ & Mild steel & $1 \mathrm{M} \mathrm{HCl}\left(35^{\circ} \mathrm{C}\right)$ & $38.8-44.5$ & 118 \\
\hline $\begin{array}{l}\text { (E)-3-(4-Methoxystyryl)-7- } \\
\text { methylquinoxalin-2(1H)-one }\end{array}$ & C35 carbon steel & $1 \mathrm{M} \mathrm{HCl}\left(30^{\circ} \mathrm{C}\right)$ & 34.9 & 125 \\
\hline $\begin{array}{l}\text { 1,4-Dihydroquinoxaline-2,3-dione } \\
\text { derivatives }\end{array}$ & Mild steel & $\begin{array}{c}1 \mathrm{M} \mathrm{H}_{2} \mathrm{SO}_{4} \\
\left(30^{\circ} \mathrm{C}\right)\end{array}$ & $\begin{array}{l}23 \pm 1 \text { (Langmuir } \\
\text { adsorption } \\
\text { isotherm). } \\
27 \text { (Temkin } \\
\text { adsorption } \\
\text { isotherm) }\end{array}$ & 128 \\
\hline $\begin{array}{l}\text { 7-Methoxypyrido[2,3-d]pyrimidin- } \\
\text { 4-amine; } \\
\text { 4-amino-7-methoxypyrido[2,3- } \\
\text { d]pyrimidin-2(1H)-one }\end{array}$ & Mild steel & $\begin{array}{c}15 \% \mathrm{HCl}(30- \\
\left.60^{\circ} \mathrm{C}\right)\end{array}$ & $\begin{array}{l}35.0-37.5 \\
36.7-38.2\end{array}$ & 131 \\
\hline $\begin{array}{l}\text { 5-Styryl-2,7-dithioxo-2,3,5,6,7,8- } \\
\text { hexahydropyrimido [4,5-d] } \\
\text { pyrimidin-4(1H)one; } \\
\text { 5-(2-hydroxyphenyl)-2,7-dithioxo- } \\
\text { 2,3,5,6,7,8-hexahydropyrimido[4,5- } \\
\text { d]-pyrimidin-4(1H)one }\end{array}$ & N80 steel & $15 \% \mathrm{HCl}\left(35^{\circ} \mathrm{C}\right)$ & $\begin{array}{l}32.7 \\
32.3\end{array}$ & 132 \\
\hline
\end{tabular}

*Adsorption energy data presented without additional clarification were calculated from the Langmuir isotherm.

\section{Composite CIs based on nitrogen-containing six-membered heterocyclic compounds}

Due to the drawbacks of $\mathrm{N}$-containing six-membered heterocyclic CIs considered above, a more interesting approach involves the creation of mixed CIs on their basis. This approach is easy to implement and it does not require a chemical modification of the starting $\mathrm{N}$-containing heterocycles. The literature that we reviewed contains a few successful implementations of this approach, including the creation of industrial corrosion inhibitors.

The "ChM" inhibitor that consisted of two components, i.e., a pickling regulator (a mixture of quinoline bases) and a foaming agent, was the first CI for metals in acids produced in the USSR . It was used in the pickling of ferrous metals in $\mathrm{H}_{2} \mathrm{SO}_{4}$ solutions 
with $t \leq 60^{\circ} \mathrm{C}$. Based on a modified pyridine - Katapin B-300 - the "KI-1" corrosion inhibitor (25\% Katapin, 25\% urotropine, balance water) was produced, which was recommended for the protection of carbon steels in $\mathrm{HCl}, \mathrm{H}_{2} \mathrm{SO}_{4}, \mathrm{H}_{3} \mathrm{PO}_{4}$ and $\mathrm{HF}$ solutions $\left(20-100^{\circ} \mathrm{C}\right)$. It provided $\mathrm{Z} \geq 97 \%$ in $\mathrm{HCl}$ and $\mathrm{H}_{2} \mathrm{SO}_{4}$ solutions. CIs of $\mathrm{S}-5$ series are synergistic mixtures of heavy pyridine and quinoline bases (cationic component) with bottom products from coke gas treatment (anionic component) in $1: 4$ component ratio. Modification of S-5U corrosion inhibitor makes it possible to protect carbon steels in solutions of $\mathrm{HCl}, \mathrm{H}_{2} \mathrm{SO}_{4}, \mathrm{H}_{3} \mathrm{PO}_{4}, \mathrm{HNO}_{3}$, acetic, formic and citric acids [11].

The active base of the BA-6 inhibitor is a mixture of 1,3,5-tribenzyltrihydro-1,3,5triazine and $N$-methylbenzylamino- $N^{\prime}$-benzyliminomethylene. This CI well protects carbon steels in $\mathrm{HCl}$ solutions, but it is not always sufficiently efficient in $\mathrm{H}_{2} \mathrm{SO}_{4}$ [11]. Synergism was also noted in the action of an equimolar mixture of 1,3,5-tribenzyltrihydro1,3,5-triazine and benzylanilinium chloride on mild steel corrosion in $\mathrm{HCl}$ and $\mathrm{H}_{2} \mathrm{SO}_{4}$ solutions [143]. The authors believe that the synergism of action of these mixed components results from the positive attractive interaction of their molecules on steel surface resulting in the mutual enhancement of CI adsorption.

$\mathrm{N}$-Dodecylpyridinium bromide, which is marketed by its developers as a surfactant [144-149], is an important component of CIs for high-temperature hydrochloric acid corrosion of steels based on unsaturated organic compounds. Probably, the role of the additive in such mixtures is not so unambiguous, since the multicomponent hightemperature CIs for steels in acids that were produced in USSR contained BA-6 [150] that also incorporated a nitrogen-containing heterocycle, viz., 1,3,5-tribenzyltrihydro-1,3,5triazine.

Unlike in hydrochloric media, six-membered $\mathrm{N}$-containing heterocycles often weakly hinder the corrosion of steels in $\mathrm{H}_{2} \mathrm{SO}_{4}, \mathrm{HClO}_{4}, \mathrm{H}_{3} \mathrm{PO}_{4}$ and $\mathrm{HNO}_{3}$ solutions. A known method for improving the protective effect of organic CIs in these media involves combining them with anionic additives, e.g., halide anions [21]. We already discussed above the possibility of improving the protective effect of substituted pyrimidines in corrosion of carbon steel in $\mathrm{HNO}_{3}$ solutions by KI addition [52]. The synergism of action of the components of a mixture containing a substituted quinoline and halide ions on the corrosion of mild steel in $0.5 \mathrm{M} \mathrm{H}_{2} \mathrm{SO}_{4}$ is noted [108].

In our opinion, it is more promising to protect steels in these acids by combinations of nitrogen-containing heterocycles with S-containing compounds. For example, a small addition of KNCS to triazines with the formula

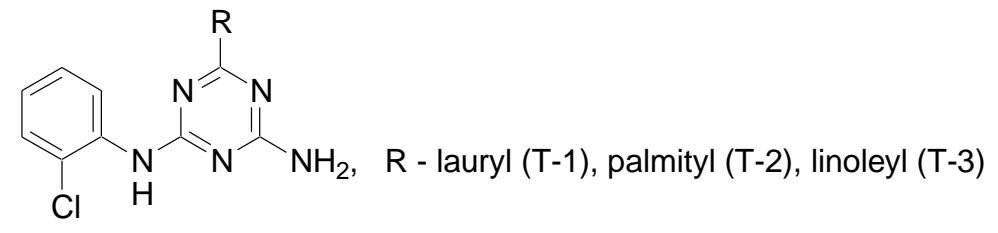

makes it possible to obtain CIs capable of hindering mild steel corrosion in $\mathrm{H}_{3} \mathrm{PO}_{4}$ solutions at $t \leq 80^{\circ} \mathrm{C}$ (Table 3). Voltammetric measurements show that the efficient 
inhibition of steel corrosion by the formulations studied results from a considerable hindrance of the cathodic and anodic reactions on steel in $\mathrm{H}_{3} \mathrm{PO}_{4}$ by these mixtures in comparison with the CI components taken separately (Figure 2) [79].

Table 3. Corrosion rates of St3 mild steel $\left(k, \mathrm{~g} /\left(\mathrm{m}^{2} \cdot \mathrm{h}\right)\right)$ and coefficients of corrosion inhibition $(\gamma)$ in $2 \mathrm{M}$ $\mathrm{H}_{3} \mathrm{PO}_{4}$ by substituted triazines and their compositions with $\mathrm{KNCS}$ at various temperatures. Test duration: $2 \mathrm{~h}$.

\begin{tabular}{|c|c|c|c|c|c|c|}
\hline \multirow{2}{*}{ Inhibitor } & \multirow{2}{*}{$k, \gamma$} & \multicolumn{5}{|c|}{ Temperature } \\
\hline & & $25^{\circ} \mathrm{C}$ & $40^{\circ} \mathrm{C}$ & $60^{\circ} \mathrm{C}$ & $80^{\circ} \mathrm{C}$ & $95^{\circ} \mathrm{C}$ \\
\hline- & $k$ & 5.8 & 20 & 38 & 141 & 518 \\
\hline \multirow{2}{*}{$5.0 \mathrm{mM} \mathrm{T}-1$} & $k$ & 3.0 & 5.0 & 21 & - & - \\
\hline & $\gamma$ & 1.9 & 4.0 & 1.8 & - & - \\
\hline \multirow{2}{*}{$5.0 \mathrm{mM} \mathrm{T}-2$} & $k$ & 4.2 & 11 & 83 & - & - \\
\hline & $\gamma$ & 1.4 & 1.8 & 0.46 & - & - \\
\hline \multirow{2}{*}{$5.0 \mathrm{mM} \mathrm{T}-3$} & $k$ & 2.7 & 4.7 & 15 & 320 & - \\
\hline & $\gamma$ & 2.1 & 4.3 & 2.5 & 0.45 & - \\
\hline \multirow{2}{*}{$0.5 \mathrm{mM}$ KNCS } & $k$ & 6.6 & 16 & 31 & 78 & 315 \\
\hline & $\gamma$ & 0.88 & 1.3 & 1.2 & 1.8 & 1.6 \\
\hline \multirow{2}{*}{$4.5 \mathrm{mM} \mathrm{T}-1+0.5 \mathrm{mM} \mathrm{KNCS}$} & $k$ & 0.50 & 0.73 & 1.3 & 3.7 & 596 \\
\hline & $\gamma$ & 12 & 27 & 29 & 38 & 0.87 \\
\hline \multirow{2}{*}{$4.5 \mathrm{mM} \mathrm{T}-2+0.5 \mathrm{mM} \mathrm{KNCS}$} & $k$ & 0.69 & 0.95 & 1.6 & 12 & 606 \\
\hline & $\gamma$ & 8.4 & 21 & 24 & 12 & 0.85 \\
\hline \multirow{2}{*}{$4.5 \mathrm{mM} \mathrm{T}-3+0.5 \mathrm{mM} \mathrm{KNCS}$} & $k$ & 0.35 & 0.53 & 0.93 & 1.6 & 251 \\
\hline & $\gamma$ & 17 & 38 & 41 & 88 & 2.1 \\
\hline
\end{tabular}

The ecological effect of the industrial application of the CI group under consideration is worthy of attention. Pyridine, quinoline, and their derivatives are toxic by themselves, which limits their usage at modern industrial plants that maintain stringent requirements for labour conditions and ecological safety of the plants. We cannot agree with W.W. Frenier and D.G. Hill who consider $N$-dodecylpyridinium bromide as a "green" CI [149]. In this context, it seems promising to search for CIs from among six-membered heterocycles with two or more $\mathrm{N}$ atoms. CIs obtained by modification of natural raw materials show promise. For example, 6-substituted $N$-(2-chlorophenyl)-1,3,5-triazine-2,4diamines (T-1, T-2 and T-3) are synthesized from methyl esters of fatty acids derived from plant oils, such as coconut, palm and sunflower oils [79]. 


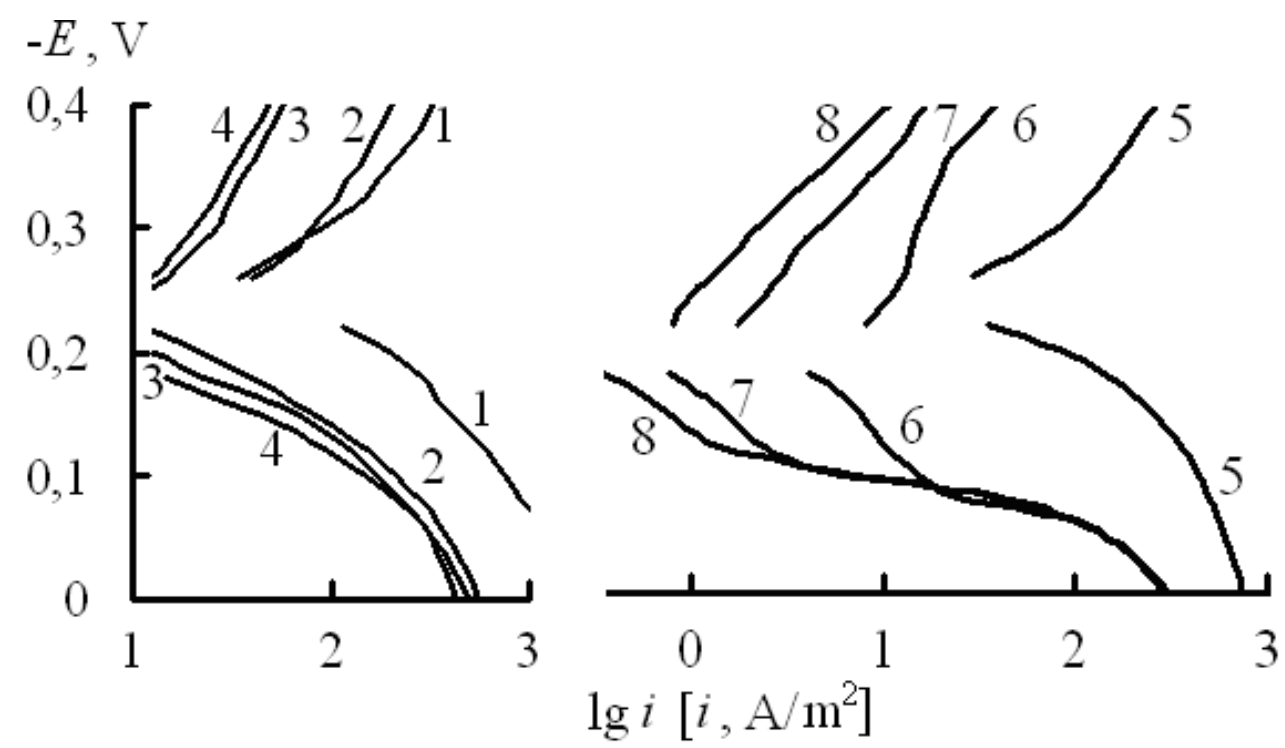

Figure 2. Polarization curves on St3 mild steel at $t=60^{\circ} \mathrm{C}$ in $2 \mathrm{M} \mathrm{H}_{3} \mathrm{PO}_{4}(1)$ with addition of 5.0 mM T-1 (2), 5.0 mM T-2 (3), 5.0 mM T-3 (4), 0.5 mM KNCS (5), 4.5 mM T-1 + 0.5 mM $\operatorname{KNCS}(6), 4.5 \mathrm{mM} \mathrm{T}-2+0.5 \mathrm{mM} \operatorname{KNCS}(7), 4.5 \mathrm{mM} \mathrm{T}-3+0.5 \mathrm{mM} \operatorname{KNCS}(8)$.

\section{Conclusion}

$\mathrm{N}$-Containing six-membered heterocyclic compounds are prone to adsorption on metal surfaces from mineral acid solutions. Based on the $\left(-\Delta G_{\mathrm{a}}^{0}\right)$ values of these CIs on metal surfaces, it can be deemed with high probability that they are mostly bound to a metal by physical forces, but upon adsorption on its surface that slow down the cathodic and anodic reactions, and eventually inhibit its corrosion. Compounds containing S atoms or bulky substituents are most interesting. These compounds are adsorbed on metals more strongly and behave as more efficient CIs. It often happens that such CIs hinder metal corrosion in $\mathrm{HCl}$ solutions but do it much more weakly in $\mathrm{H}_{2} \mathrm{SO}_{4}, \mathrm{HClO}_{4}$, and $\mathrm{H}_{3} \mathrm{PO}_{4}$. The heterocycles discussed above behave as CIs in "cold" solutions but lose these properties at higher temperatures. Examples of the use of six-membered $\mathrm{N}$-containing heterocycles as CIs of various steels and non-ferrous metals $(\mathrm{Al}, \mathrm{Cu}, \mathrm{Sn}, \mathrm{Zn}$ and their alloys) are available in literature.

The industrial application of individual six-membered $N$-containing heterocycles and their derivatives for metal protection in acid media is of little promise and is unjustified. It is more appropriate to use these compounds as components of inhibitor mixtures. Mixed CIs containing these compounds can hinder corrosion even in such corrosive media as high-temperature $\mathrm{HCl}$ solutions or hot $\mathrm{H}_{3} \mathrm{PO}_{4}$ solutions. The base for creating prospective mixed corrosion inhibitors for metals in acids should be searched for among six-membered heterocyclic compounds containing two or more nitrogen atoms or compounds obtained from natural raw materials. 


\section{References}

1. ISO Standard 8044-1989.

2. Yu.I. Kuznetsov, Organic Inhibitors of Corrosion of Metals, New York, Plenum Press, 1996, 283 pp.

3. Yu.I. Kuznetsov, Physicochemical aspects of metal corrosion inhibition in aqueous solutions, Russ. Chem. Rev., 2004, 73, no. 1, 75-87. doi: 10.1070/RC2004v073n01 $\underline{\mathrm{ABEH} 000864}$

4. N.N. Andreev and Yu.I. Kuznetsov, Physicochemical aspects of the action of volatile metal corrosion inhibitors, Russ. Chem. Rev., 2005, 74, no. 8, 685-695. doi: 10.1070/RC2005v074n08ABEH001162

5. Yu.I. Kuznetsov and L.P. Kazansky, Physicochemical aspects of metal protection by azoles as corrosion inhibitors, Russ. Chem. Rev., 2008, 77, no. 3, 219-232. doi: 10.1070/RC2008v077n03ABEH003753

6. Yu.I. Kuznetsov, Organic corrosion inhibitors: where are we now? A review. Part I. Adsorption, Int. J. Corros. Scale Inhib., 2015, 4, no. 4, 284-310. doi: 10.17675/23056894-2015-4-4-1

7. Yu.I. Kuznetsov, Organic corrosion inhibitors: where are we now? A review. Part II. Passivation and the role of chemical structure of carboxylates, Int. J. Corros. Scale Inhib., 2016, 5, no. 4, 282-318. doi: 10.17675/2305-6894-2016-5-4-1

8. Yu.I. Kuznetsov, Organic corrosion inhibitors: where are we now? A review. Part III. Passivation and the role of the chemical structure of organophosphates, Int. J. Corros. Scale Inhib., 2017, 6, no. 3, 209-239. doi: 10.17675/2305-6894-2017-6-3-1

9. Yu.I. Kuznetsov, Organic corrosion inhibitors: where are we now? A review. Part IV. Passivation and the role of mono- and diphosphonates, Int. J. Corros. Scale Inhib., 2017, 6, no. 4, 384-427. doi: 10.17675/2305-6894-2017-6-4-3

10. S.M. Reshetnikov, Ingibitory kislotnoi korrozii metallov (Metal Corrosion Inhibitors in Acids), Khimiya, Leningrad, 1986, 144 pp. (in Russian).

11. E.S. Ivanov, Ingibitory korrozii metallov v kislykh sredakh (Metal Corrosion Inhibitors in Acidic media), Metallurgiya, Moscow, 1986, 175 pp. (in Russian).

12. G. Schmitt, Application of Inhibitors for Acid Media, Br. Corros. J., 1984, 19, no. 4, 165-176.

13. Ya.G. Avdeev and Yu.I. Kuznetsov, Physicochemical aspects of inhibition of acid corrosion of metals by unsaturated organic compounds, Russ. Chem. Rev., 2012, 81, no. 12, 1133-1145. doi: 10.1070/RC2012v081n12ABEH004292

14. N.I. Podobaev and Ya.G. Avdeev, A Review of Acetylene Compounds as Inhibitors of Acid Corrosion of Iron, Prot. Met., 2004, 40, no. 1, 7-13.

15. Ya.G. Avdeev, Protection of Steel in Solutions of Mineral Acids Using $\alpha, \beta-$ Unsaturated Aldehydes, Ketones, and Azomethines, Prot. Met. Phys. Chem. Surf., 2015, 51, no. 7, 1140-1148. doi: 10.1134/S2070205115070023 
16. R.K. Vagapov, Yu.I. Kuznetsov and A.V. Agafonkin, Ingibirovaniye korrozii metallov osnovaniyami Shiffa $v$ rastvorakh mineral'nykh kislot (Inhibition of metal corrosion in solutions of mineral acids by Schiff bases), Korroz.: mater., zashch., 2013, no. 4, 3746 (in Russian).

17. Ya.G. Avdeev and M.V. Tyurina, Ingibitornaya zashchita metallov $\mathrm{v}$ rastvorakh fosfornoy kisloty (Inhibitory protection of metals in solutions of phosphoric acid), Korroz.: mater., zashch., 2016, no. 2, 7-19 (in Russian).

18. M. Finšgar and J. Jackson, Application of corrosion inhibitors for steels in acidic media for the oil and gas industry: A review, Corros. Sci., 2014, 86, 17-41. doi: 10.1016/j.corsci.2014.04.044

19. A. Singh and M.A. Quraishi, Acidizing Corrosion Inhibitors: A Review, J. Mater. Environ. Sci., 2015, 6, no. 1, 224-235.

20. S.A. Abd El-Maksoud, The Effect of Organic Compounds on the Electrochemical Behaviour of Steel in Acidic Media. A review, Int. J. Electrochem. Sci., 2008, 3, 528555.

21. S.A. Umoren and M.M. Solomon, Effect of halide ions on the corrosion inhibition efficiency of different organic species - A review, J. Ind. Eng. Chem., 2015, 21, 81100. doi: $10.1016 /$ j.jiec.2014.09.033

22. R.T. Loto, C.A. Loto and A.P.I. Popoola, Corrosion inhibition of thiourea and thiadiazole derivatives: A Review, J. Mater. Environ. Sci., 2012, 3, no. 5, 885-894.

23. S.A. Umoren and M.M. Solomon, Recent Developments on the Use of Polymers as Corrosion Inhibitors - A Review, Open Mater. Sci. J., 2014, 8, 39-54.

24. G. Gece, Drugs: A review of promising novel corrosion inhibitors, Corros. Sci., 2011, 53, 3873-3898. doi: 10.1016/j.corsci.2011.08.006

25. S. Hooshmand Zaferani, M. Sharifi, D. Zaarei and M. Reza Shishesaz, Application of eco-friendly products as corrosion inhibitors for metals in acid pickling processes - A review, J. Environ. Chem. Eng., 2013, 1, 652-657. doi: 10.1016/j.jece.2013.09.019

26. Ambrish Singh, Eno E. Ebenso and M.A. Quraishi, Corrosion Inhibition of Carbon Steel in $\mathrm{HCl}$ Solution by Some Plant Extracts, Int. J. Corros., 2012, 2012, Article ID 897430, 20 pp. doi: 10.1155/2012/897430

27. K. Rasheeda, Vijaya D.P. Alva, P.A. Krishnaprasad and S. Samshuddin, Pyrimidine derivatives as potential corrosion inhibitors for steel in acid medium - An overview, Int. J. Corros. Scale Inhib., 2018, 7, no. 1, 48-61. doi: 10.17675/2305-6894-2018-7-1-5

28. V.I. Ivanskiy, Khimiya geterotsiklicheskikh soyedineniy: Uchebnoye posobiye dlya universitetovtov (Chemistry of heterocyclic compounds: A tutorial for university students), Moscow, Vysshaya shkola, 1978, 559 pp. (in Russian).

29. F. Zhang, Y. Tang, Z. Cao, W. Jing, Zh. Wu and Y. Chen, Performance and theoretical study on corrosion inhibition of 2-(4-pyridyl)-benzimidazole for mild steel in hydrochloric acid, Corros. Sci., 2012, 61, 1-9. doi: 10.1016/j.corsci.2012.03.045 
30. B.I. Ita, O.U. Abakedi and V.N. Osabor, Inhibition of mild steel corrosion in hydrochloric acid by 2-acetylpyridine and 2-acetylpyridine phosphate, Global Advanced Research Journal of Engineering, Technology and Innovation, 2013, March, 2, no. 3, 84-89.

31. A.O. James and N.C. Oforka, 2-Benzoyl pyridine: An inhibitor for mild steel corrosion in hydrochloric acid solution, Adv. Appl. Sci. Res., 2014, 5, no. 2, 1-6.

32. A.O. James, N.C. Oforka and K. Abiola Olusegun, Anti-corrosive Properties of 2Benzoyl Pyridine on Aluminium Corrosion in Hydrochloric Acid Solution, J. Sci. Res. Dev., 2011, 13, 1-10.

33. A. Kosari, M.H. Moayed, A. Davoodi, R. Parvizi, M. Momeni, H. Eshghi and H. Moradi, Electrochemical and quantum chemical assessment of two organic compounds from pyridine derivatives as corrosion inhibitors for mild steel in $\mathrm{HCl}$ solution under stagnant condition and hydrodynamic flow, Corros. Sci., 2014, 78, 138-150. doi: 10.1016/j.corsci.2013.09.009

34. B. Xu, Y. Liu, X. Yin, W. Yang and Y. Chen, Experimental and theoretical study of corrosion inhibition of 3-pyridinecarbozalde thiosemicarbazone for mild steel in hydrochloric acid, Corros. Sci., 2013, 74, 206-213. doi: 10.1016/j.corsci.2013.04.044

35. B. Xu, W. Yang, Y. Liu, X. Yin, W. Gong and Y. Chen, Experimental and theoretical evaluation of two pyridinecarboxaldehyde thiosemicarbazone compounds as corrosion inhibitors for mild steel in hydrochloric acid solution, Corros. Sci., 2014, 78, 260-268. doi: $10.1016 /$ j.corsci.2013.10.007

36. K.F. Khaled, Electrochemical investigation and modeling of corrosion inhibition of aluminum in molar nitric acid using some sulphur-containing amines, Corros. Sci., 2010, 52, 2905-2916. doi: $10.1016 /$ j.corsci.2010.05.001

37. Y. Meng, W. Ning, B. Xu, W. Yang, K. Zhang, Y. Chen, L. Li, X. Liu, J. Zhenga and Y. Zhang, Inhibition of mild steel corrosion in hydrochloric acid using two novel pyridine Schiff base derivatives: a comparative study of experimental and theoretical results, $R S C A d v$., 2017, 7, 43014-43029. doi: 10.1039/c7ra08170g

38. M. Lebrini, F. Bentiss, H. Vezin and M. Lagrenee, The inhibition of mild steel corrosion in acidic solutions by 2,5-bis(4-pyridyl)-1,3,4-thiadiazole: Structure - activity correlation, Corros. Sci., 2006, 48, 1279-1291. doi: 10.1016/j.corsci.2005.05.001

39. F. Bentiss, B. Mernari, M. Traisnel, H. Vezin and M. Lagrenee, On the relationship between corrosion inhibiting effect and molecular structure of 2,5-bis( $n$-pyridyl)-1,3,4thiadiazole derivatives in acidic media: Ac impedance and DFT studies, Corros. Sci., 2011, 53, 487-495. doi: 10.1016/j.corsci.2010.09.063

40. R. Y1ldı, A. Doner, T. Dogan and I. Dehri, Experimental studies of 2pyridinecarbonitrile as corrosion inhibitor for mild steel in hydrochloric acid solution, Corros. Sci., 2014, 82, 125-132. doi: 10.1016/j.corsci.2014.01.008

41. S.A. Abd El-Maksoud and A.S. Fouda, Some pyridine derivatives as corrosion inhibitors for carbon steel in acidic medium, Mater. Chem. Phys., 2005, 93, no. 1, 8490. doi: $\underline{10.1016 / \mathrm{j} . \text { matchemphys.2005.02.020 }}$ 
42. K.R. Ansari, M.A. Quraishi and Ambrish Singh, Corrosion inhibition of mild steel in hydrochloric acid by some pyridine derivatives: An experimental and quantum chemical study, J. Ind. Eng. Chem., 2015, 25, 89-98. doi: 10.1016/j.jiec.2014.10.017

43. K.R. Ansari, M.A. Quraishi and Ambrish Singh, Pyridine derivatives as corrosion inhibitors for $\mathrm{N} 80$ steel in 15\% $\mathrm{HCl}$ : Electrochemical, surface and quantum chemical studies, Measurement, 2015, 76, 136-147. doi: j.measurement.2015.08.028

44. Y. Ji, B. Xu, W. Gong, X. Zhang, X. Jin, W. Ning, Y. Meng, W. Yang and Y. Chen, Corrosion inhibition of a new Schiff base derivative with two pyridine rings on Q235 mild steel in $1.0 \mathrm{M} \mathrm{HCl}$, J. Taiwan Inst. Chem. Eng., 2016, 66, 301-312. doi: 10.1016/j.jtice.2016.07.007

45. A.I. Altsibeeva and S.Z. Levin, Ingibitory korrozii metallov. Spravochnik (Metal Corrosion Inhibitors. Handbook), Khimiya, Leningrad, 1968, 264 pp. (in Russian).

46. E.A. Noor, Evaluation of inhibitive action of some quaternary $\mathrm{N}$-heterocyclic compounds on the corrosion of Al-Cu alloy in hydrochloric acid, Mater. Chem. Phys., 2009, 114, 533-541. doi: 10.1016/j.matchemphys.2008.09.065

47. I. Lukovits, E. Kalman and F. Zucchi, Corrosion inhibitors - correlation between electronic structure and efficiency, Corrosion, 2001, 57, no. 1, 3-8.

48. K.F. Khaled, Modeling corrosion inhibition of iron in acid medium by genetic function approximation method: A QSAR model, Corros. Sci., 2011, 53, 3457-3465. doi: 10.1016/j.corsci.2011.01.035

49. R. Y1ldiz, An electrochemical and theoretical evaluation of 4,6-diamino-2pyrimidinethiol as a corrosion inhibitor for mild steel in $\mathrm{HCl}$ solutions, Corros. Sci., 2015, 90, 544-553. doi: 10.1016/j.corsci.2014.10.047

50. H.E. Megahed, Electrobioremediation of Patagonian Soils Contaminated with Hydrocarbons, Port. Electrochim. Acta, 2012, 30, no. 6, 427-435. doi: 10.4152/pea.201206427

51. X. Li and X. Xie, Adsorption and inhibition effect of two aminopyrimidine derivatives on steel surface in $\mathrm{H}_{2} \mathrm{SO}_{4}$ solution, J. Taiwan Inst. Chem. Eng., 2014, 45, 3033-3045. doi: $10.1016 /$ j.jtice.2014.08.019

52. M. Abdallah, E.A. Helal and A.S. Fouda, Aminopyrimidine derivatives as inhibitors for corrosion of 1018 carbon steel in nitric acid solution, Corros. Sci., 2006, 48, 16391654. doi: $10.1016 /$ j.corsci.2005.06.020

53. G.Y. Elewady, Pyrimidine Derivatives as Corrosion Inhibitors for Carbon-Steel in $2 \mathrm{M}$ Hydrochloric Acid Solution, Int. J. Electrochem. Sci., 2008, 3, 1149-1161.

54. M.M. El-Naggar, Corrosion inhibition of mild steel in acidic medium by some sulfa drugs compounds, Corros. Sci., 2007, 49, 2226-2236. doi: 10.1016/j.corsci.2006. $\underline{10.039}$

55. X. Li, X. Xie, S. Deng and G. Du, Two phenylpyrimidine derivatives as new corrosion inhibitors for cold rolled steel in hydrochloric acid solution, Corros. Sci., 2014, 87, $27-$ 39. doi: 10.1016/j.corsci.2014.05.017 
56. O.K. Abiola, Adsorption of 3-(4-amino-2-methyl-5-pyrimidylmethyl)-4-methyl thiazolium chloride on mild steel, Corros. Sci., 2006, 48, 3078-3090. doi: 10.1016/j.corsci.2005.12.001

57. R. Solmaz, Investigation of corrosion inhibition mechanism and stability of Vitamin B1 on mild steel in $0.5 \mathrm{M} \mathrm{HCl}$ solution, Corros. Sci., 2014, 81, 75-84. doi: 10.1016/j.corsci.2013.12.006

58. X. Lia, S. Deng, T. Lin, X. Xie and G. Du, 2-Mercaptopyrimidine as an effective inhibitor for the corrosion ofcold rolled steel in $\mathrm{HNO}_{3}$ solution, Corros. Sci., 2017, 118, 202-216. doi: 10.1016/j.corsci.2017.02.011

59. N. Anusuya, J. Saranya, P. Sounthari, A. Zarrouk and S. Chitra, Corrosion inhibition and adsorption behaviour of some bis-pyrimidine derivatives on mild steel in acidic medium, J. Mol. Liq., 2017, 225, 406-417. doi: 10.1016/j.molliq.2016.11.015

60. D.K. Yadav, B. Maiti and M.A. Quraishi, Electrochemical and quantum chemical studies of 3,4-dihydropyrimidin-2(1H)-ones as corrosion inhibitors for mild steel in hydrochloric acid solution, Corros. Sci., 2010, 52, 3586-3598. doi: 10.1016/j.corsci.2010.06.030

61. N. Caliskan and E. Akbas, Corrosion inhibition of austenitic stainless steel by some pyrimidine compounds in hydrochloric acid, Mater. Corros., 2012, 63, no. 3, 231-237. doi: $\underline{10.1002 / \mathrm{maco} .201005788}$

62. D.M. Gurudatt and K.N.Sh. Mohana, Influence of some synthesized pyrimidine derivatives on corrosion inhibition of mild steel in hydrochloric acid medium, Eur. $J$. Chem., 2014, 5, no. 1, 53-64. doi: 10.5155/eurjchem.5.1.53-64.899

63. C. Verma, L.O. Olasunkanmi, E.E. Ebenso and M.A. Quraishi, Adsorption characteristics of green 5-arylaminomethylene pyrimidine-2,4,6-triones on mild steel surface in acidic medium: Experimental and computational approach, Results Phys., 2018, 8, 657-670. doi: 10.1016/j.rinp.2018.01.008

64. X. Li, S. Deng and H. Fu, Three pyrazine derivatives as corrosion inhibitors for steel in $1.0 \mathrm{M} \mathrm{H}_{2} \mathrm{SO}_{4}$ solution, Corros. Sci., 2011, 53, 3241-3247. doi: 10.1016/j.corsci.2011. $\underline{05.068}$

65. X. Li, S. Deng and H. Fu, Two pyrazine derivatives as inhibitors of the cold rolled steel corrosion in hydrochloric acid solution, Corros. Sci., 2011, 53, 822-828. doi: 10.1016/j.corsci.2010.11.019

66. I.B. Obot and Z.M. Gasem, Theoretical evaluation of corrosion inhibition performance of some pyrazine derivatives, Corros. Sci., 2014, 83, 359-366. doi: 10.1016/j.corsci.2014.03.008

67. A. Chetouani, B. Hammouti, A. Aouniti, N. Benchat and T. Benhadda, New synthesised pyridazine derivatives as effective inhibitors for the corrosion of pure iron in $\mathrm{HCl}$ medium, Progr. Org. Coat., 2002, 45, 373-378. doi: 10.1016/S03009440(02)00123-6 
68. A. Chetouani, A. Aouniti, B. Hammouti, N. Benchat, T. Benhadda and S. Kertit, Corrosion inhibitors for iron in hydrochloride acid solution by newly synthesised pyridazine derivatives, Corros. Sci., 2003, 45, 1675-1684. doi: 10.1016/S0010938X(03)00018-0

69. Z. El Adnani, M. Mcharfi, M. Sfaira, A.T. Benjelloun, M. Benzakour, M. Ebn Touhami, B. Hammouti and M. Taleb, Investigation of Newly Pyridazine Derivatives as Corrosion Inhibitors in Molar hydrochloric Acid. Part III: Computational Calculations, Int. J. Electrochem. Sci., 2012, 7, 3982-3996.

70. A. Ghazoui, N. Bencaht, S.S. Al-Deyab, A. Zarrouk, B. Hammouti, M. Ramdani and M. Guenbour, An Investigation of Two Novel Pyridazine Derivatives as Corrosion Inhibitor for C38 Steel in 1.0 M HCl, Int. J. Electrochem. Sci., 2013, 8, 2272-2292.

71. H. Zarrok, R. Saddik, H. Oudda, B. Hammouti, A. El Midaoui, A. Zarrouk, N. Benchat and M. Ebn Touhami, 5-(2-Chlorobenzyl)-2,6-Dimethylpyridazin-3-One: An efficient Inhibitor of C38 Steel Corrosion in Hydrochloric Acid, Pharma Chem., 2011, 3, no. 5, $272-282$.

72. H. Zarrok, H. Oudda, A. Zarrouk, R. Salghi, B. Hammouti and M. Bouachrine, Weight Loss Measurement and Theoretical Study of New Pyridazine Compound as Corrosion Inhibitor for C38 Steel in Hydrochloric Acid Solution, Pharma Chem., 2011, 3, no. 6, 576-590.

73. A. Zarrouk，H. Zarrok，R. Salghi，R. Touir，B. Hammouti，N. Benchat，L.L. Afrine, H. Hannache, M. El Hezzat and M. Bouachrine, Electrochemical impedance spectroscopy weight loss and quantum chemical study of new pyridazine derivative as inhibitor corrosion of copper in nitric acid, J. Chem. Pharm. Res., 2013, 5, no. 12, $1482-1491$.

74. K. Benbouya, I. Forsal, M. Elbakri, T. Anik, R. Touir, M. Bennajah, D. Chebab, A. Rochdi, B. Mernari and M. Ebn Touhami, Influence of pyridazine derivative on corrosion inhibition of mild steel in acidic media, Res. Chem. Intermed., 2014, 40, 1267-1281. doi: 10.1007/s11164-013-1037-z

75. A. Khadiri, R. Saddik, K. Bekkouche, A. Aouniti, B. Hammouti, N. Benchat, M. Bouachrine and R. Solmaz, Gravimetric, electrochemical and quantum chemical studies of some pyridazine derivatives as corrosion inhibitors for mild steel in $1 \mathrm{M} \mathrm{HCl}$ solution, J. Taiwan Inst. Chem. Eng., 2016, 58, 552-564. doi: 10.1016/j.jtice.2015.06. $\underline{031}$

76. O.I. Sizaya and A.P. Andrushko, On the Use of Triazines as Inhibitors of Steel Corrosion, Prot. Met., 2004, 40, no. 2, 164-168.

77. H.I. Al-Shafey, O.E. El Azabawy and E.A. Ismail, Ethoxylated Melamine as Corrosion Inhibitor for Carbon Steel in 1M HCl, J. Dispersion Sci. Technol., 2011, 32, 995-1001. doi: 10.1080/01932691.2010.497427

78. X.H. Pang, M. Gong, Y.X. Zhang, Q. Wei and B.R. Hou, Corrosion inhibition and mechanism of mild steel in hydrochloric acid by ceftriaxone and amoxicillin, Sci. China Chem., 2011, 54, no. 9, 1529-1536. doi: 10.1007/s11426-011-4332-9 
79. Ya.G. Avdeev, M.V. Tyurina, Yu.I. Kuznetsov, H.S. Shikhaliev, N.V. Stolpovskaya and A.S. Peregudova, Vliyaniye proizvodnykh $N$-(2-khlorfenil)-1,3,5-triazin-2,4diamina na elektrodnyye reaktsii i korroziyu nizkouglerodistoy stali $\mathrm{v}$ mineral'nykh kislotakh (Effect of $\mathrm{N}$-(2-chlorophenyl)-1,3,5-triazine-2,4-diamine derivatives on electrode reactions and corrosion of low-carbon steel in mineral acids), Korroz.: mater., zashch., 2015, no. 10, 32-38 (in Russian).

80. S. John and A. Joseph, Effective inhibition of mild steel corrosion in 1 M hydrochloric acid using substituted triazines: an experimental and theoretical study, RSC Adv., 2012, 2, 9944-9951. doi: 10.1039/C2RA20663C

81. S. John and A. Joseph, Quantum chemical and electrochemical studies on the corrosion inhibition of aluminium in $1 \mathrm{~N}^{\mathrm{HNO}_{3}}$ using 1,2,4-triazine, Mater. Corros., 2013, 64, no. 7, 625-632. doi: $10.1002 / \mathrm{maco} .201206782$

82. S.K. Shukla, S.A. Kumar and M.A. Quraishi, Triazines: Efficient Corrosion Inhibitors for Mild Steel in Hydrochloric Acid Solution, Int. J. Electrochem. Sci., 2012, 7, 33713389.

83. D.O. Isin and N. Karakus, Quantum chemical study on the inhibition efficiencies of some sym-triazines as inhibitors for mild steel in acidic medium, J. Taiwan Inst. Chem. Eng., 2015, 50, 306-313. doi: 10.1016/j.jtice.2014.12.035

84. A.M. Al-Sabagh, N.Gh. Kandile, N.M. Nasser, M.R. Mishrif and E. El-Tabey Amira, Novel surfactants incorporated with 1,3,5-triethanolhexahydro-1,3,5-triazine moiety as corrosion inhibitors for carbon steel in hydrochloric acid: Electrochemical and quantum chemical investigations, Egypt. J. Pet., 2013, 22, 351-365. doi: 10.1016/j.ejpe.2013. 10.004

85. N.I. Podobayev and N.I. Savitkin, Issledovaniye adsorbtsii 1,3,5-tribenziltrigidro-simtriazina iz kislykh sul'fatnykh rastvorov na zheleze (Investigation of the adsorption of 1,3,5-tribenzyltrihydro-sym-triazine from acid sulfate solutions on iron)," Zhurnal fizicheskoy khimii (Russ. J. Phys. Chem. A), 1975, 49, no. 4, 1030-1031 (in Russian).

86. N.I. Podobayev and N.I. Savitkin, Zapolneniye poverkhnosti zheleza 1,3,5tribenziltrigidrosimtriazinom i tormozheniye vosstanovleniya vodoroda (Filling of the surface of iron by 1,3,5-tribenzyltrihydrosymtriazine and inhibition of hydrogen reduction), Zashch. met., 1977, 13, no. 3, 336-338 (in Russian).

87. L. Elkadi, B. Mernari, M. Traisnel, F. Bentiss and M. Lagrenee, The inhibition action of 3,6-bis(2-methoxyphenyl)-1,2-dihydro-1,2,4,5-tetrazine on the corrosion of mild steel in acidic media, Corros. Sci., 2000, 42, 703-719. doi: 10.1016/S0010938X(99)00101-8

88. F. Bentiss, M. Outirite, M. Traisnel, H. Vezin, M. Lagrenee, B. Hammouti, S.S. AlDeyab and C. Jama, Improvement of Corrosion Resistance of Carbon Steel in Hydrochloric Acid Medium by 3,6-bis(3-Pyridyl)Pyridazine, Int. J. Electrochem. Sci., 2012, 7, 1699-1723. 
89. X. Pang, B. Hou, W. Li, F. Liu and Z. Yu, 2,3,5-Triphenyl-2H-tetrazolium Chloride and 2,4,6-Tri(2-pyridyl)-striazine on the Corrosion of Mild Steel in HCl, Chin. J. Chem. Eng., 2007, 15, no. 6, 909-915. doi: 10.1016/S1004-9541(08)60024-5

90. A.-R. El-Sayed, H.S. Mohran and H.M. Abd El-Lateef, The inhibition effect of 2,4,6tris (2-pyridyl)-1,3,5-triazine on corrosion of tin, indium and tin-indium alloys in hydrochloric acid solution, Corros. Sci., 2010, 52, 1976-1984. doi: 10.1016/j.corsci.2010.02.029

91. M. Yadav, S. Kumar, N. Tiwari, I. Bahadur and E.E. Ebenso, Experimental and quantum chemical studies of synthesized triazine derivatives as an efficient corrosion inhibitor for N80 steel in acidic medium, J. Mol. Liq., 2015, 212, 151-167. doi: 10.1016/j.molliq.2015.09.019

92. E.E. Ebenso, I.B. Obot and L.C. Murulana, Quinoline and its Derivatives as Effective Corrosion Inhibitors for Mild Steel in Acidic Medium, Int. J. Electrochem. Sci., 2010, 5, 1574-1586.

93. E.E. Ebenso, M.M. Kabanda, T. Arslan, M. Saracoglu, F. Kandemirli, L.C. Murulana, A.K. Singh, S.K. Shukla, B. Hammouti, K.F. Khaled, M.A. Quraishi, I.B. Obot and N.O. Eddy, Quantum Chemical Investigations on Quinoline Derivatives as Effective Corrosion Inhibitors for Mild Steel in Acidic Medium, Int. J. Electrochem. Sci., 2012, 7, 5643-5676.

94. G. Achary, H.P. Sachin, Y. Arthoba Naik and T.V. Venkatesha, The corrosion inhibition of mild steel by 3-formyl-8-hydroxy quinoline in hydrochloric acid medium, Mater. Chem. Phys., 2008, 107, 44-50. doi: 10.1016/j.matchemphys.2007.06.038

95. H. Lgaz, R. Salghi, K. Subrahmanya Bhat, A. Chaouiki, Shubhalaxmi and S. Jodeh, Correlated experimental and theoretical study on inhibition behavior of novel quinoline derivatives for the corrosion ofmild steel in hydrochloric acid solution, J. Mol. Liq., 2017, 244, 154-168. doi: 10.1016/j.molliq.2017.08.121

96. B.M. Prasanna, B.M. Praveen, Narayana Hebbar, T.V. Venkatesha and H.C. Tandon, Inhibition study of mild steel corrosion in $1 \mathrm{M}$ hydrochloric acid solution by 2-chloro3-formyl quinoline, Int. J. Ind. Chem., 2016, 7, 9-19. doi: 10.1007/s40090-015-0064-6

97. B.S. Shylesha, T.V. Venkatesha, B.M. Praveen and K.V. Srinath, Corrosion Inhibition Effect of Substituted Quinoline and Its Condensation Products on Mild Steel in Acidic Media, Anal. Bioanal. Electrochem., 2011, 3, no. 3, 249-260.

98. B.M. Mistry, N.S. Patel, S. Sahoo and S. Jauhari, Experimental and quantum chemical studies on corrosion inhibition performance of quinoline derivatives for MS in $1 \mathrm{~N}$ HCl, Bull. Mater. Sci., 2012, 35, no. 3, 459-469.

99. K.R. Ansari, S. Ramkumar, D. Nalini and M.A. Quraishi, Studies on adsorption and corrosion inhibitive properties of quinoline derivatives on N80 steel in 15\% hydrochloric acid, Cogent Chem., 2016, 2, 1145032. doi: 10.1080/23312009. $\underline{2016.1145032}$ 
100. V.R. Saliyan and A.V. Adhikari, Quinolin-5-ylmethylene-3-\{[8-(trifluoromethyl)quinolin-4-yl]thio \}propanohydrazide as an effective inhibitor of mild steel corrosion in HCl solution," Corros. Sci., 2008, 50, 55-61. doi: 10.1016/j.corsci.2006.06.035

101. V.R. Saliyan and A.V. Adhikari, Inhibition of corrosion of mild steel in acid media by $\mathrm{N}$-benzylidene-3-(quinolin-4-ylthio)propanohydrazide, Bull. Mater. Sci., 2008, 31, no. 4, 699-711.

102. V.R. Saliyan and A.V. Adhikari, Corrosion Inhibition of mild steel in acid media by quinolinyl thiopropano hydrazone, Indian J. Chem. Technol., 2008, 15, no. 5, 238-243.

103. L. Jiang, Y. Qiang, Z. Lei, J. Wang, Z. Qin and B. Xiang, Excellent corrosion inhibition performance of novel quinoline derivatives on mild steel in $\mathrm{HCl}$ media: Experimental and computational investigations, J. Mol. Liq., 2018, 255, 53-63. doi: 10.1016/j.molliq.2018.01.133

104. P. Singh, V. Srivastava and M.A. Quraishi, Novel quinoline derivatives as green corrosion inhibitors formild steel in acidic medium: Electrochemical, SEM, AFM, and XPS studies, J. Mol. Liq., 2016, 216, 164-173. doi: 10.1016/j.molliq.2015.12.086

105. X.H. Pang, W.J. Guo, W.H. Li, J.D. Xie and B.R. Hou, Electrochemical, quantum chemical and SEM investigation of the inhibiting effect and mechanism of ciprofloxacin, norfloxacin and ofloxacin on the corrosion for mild steel in hydrochloric acid, Sci. China, Ser. B: Chem., 2008, 51, no. 10, 928-936.

106. M. Sobhi, Gatifloxacin as Corrosion Inhibitor for Carbon Steel in Hydrochloric Acid Solutions, Prot. Met. Phys. Chem. Surf., 2014, 50, no. 6, 825-832. doi: 10.1134/S2070205114060227

107. Z. Yang, F. Zhan, Y. Pan, Z. LYu, C. Han, Y. Hu, P. Ding, T. Gao, X. Zhou and Y. Jiang, Structure of a novel Benzyl Quinolinium Chloride derivative and its effective corrosion inhibition in 15 wt.\% hydrochloric acid, Corros. Sci., 2015, 99, 281-294. doi: $10.1016 /$ j.corsci.2015.07.023

108. R. Geethanjali, S. Leelavathi, S. Subhashini and R. Rajalakshmi, The Synergistic Effects of Halide Ions and Cations on the Corrosion Inhibition of Mild Steel in $\mathrm{H}_{2} \mathrm{SO}_{4}$ Using Amodiaquine, Chem. Sci. Trans., 2013, 2, no. 4, 1296-1303. doi: $10.7598 / \mathrm{cst} 2013.538$

109. P. Mourya, P. Singh, A.K. Tewari, R.B. Rastogi and M.M. Singh, Relationship between structure and inhibition behavior of quinolinium salts for mild steel corrosion: Experimental and theoretical approach, Corros. Sci., 2015, 95, 71-87. doi: 10.1016/j.corsci.2015.02.034

110. R.A. Hussein Al-Uqaily, Inhibition by 1-Methyl Isoquinoline for Mild Steel Corrosion in $1 \mathrm{M} \mathrm{HCl}$ Media, Amer. Sci. Res. J. Eng. Technol. Sci. (ASRJETS), 2015, 14, no. 1, $55-63$.

111. K.G. Sheth and T.L. Rama, Char Corrosion Inhibition of Aluminum-Zinc Alloy in Hydrochloric Acid Solutions, Corrosion, 1962, 18, no. 6, 218-223. 
112. J.J. Fu, H.S. Zang, Y. Wang, S.N. Li, T. Chen and X.D. Liu, Experimental and Theoretical Study on the Inhibition Performances of Quinoxaline and Its Derivatives for the Corrosion of Mild Steel in Hydrochloric Acid, Ind. Eng. Chem. Res., 2012, 51, 6377-6386. doi: $10.1021 /$ ie202832e

113. L.O. Olasunkanmi, M.M. Kabanda and E.E. Ebenso, Quinoxaline derivatives as corrosion inhibitors for mild steel in hydrochloric acid medium: Electrochemical and quantum chemical studies, Physica E, 2016, 76, 109-126. doi: 10.1016/j.physe.2015.10.005

114. H. Lgaz, R. Salghi, S. Jodeh, Y. Ramli, M. Larouj, K. Toumiat, M.A. Quraishi, H. Oudda and W. Jodeh, Understanding the Adsorption of Quinoxaline Derivatives as Corrosion Inhibitors for Mild Steel in Acidic Medium: Experimental, Theoretical and Molecular Dynamic Simulation Studies, J. Steel Struct. Constr., 2016, 2, 111. doi: $\underline{10.4172 / 2472-0437.1000111}$

115. K. Adardour, R. Touir, Y. Ramli, R.A. Belakhmima, M. Ebn Touhami, C. Kalonji Mubengayi, H. El Kafsaoui and E.M. Essassi, Comparative inhibition study of mild steel corrosion in hydrochloric acid by new class synthesized quinoxaline derivatives: Part I, Res. Chem. Intermed., 2013, 39, 1843-1855. doi: 10.1007/s11164-012-0719-2

116. K. Adardour, R. Touir, M. Elbakri, Y. Ramli, M. Ebn Touhami, H. El Kafsaoui, C. Kalonji Mubengayi and E.M. Essassi, Thermodynamic study of mild steel corrosion in hydrochloric acid by new class synthesized quinoxaline derivatives: Part II, Res. Chem. Intermed., 2013, 39, 4175-4188. doi: 10.1007/s11164-012-0934-x

117. S. Chitra, K. Parameswari, M. Vidhya, M. Kalishwari and A. Selvaraj, Evaluation of Quinoxalines as Corrosion Inhibitors for Mild Steel in Acid Environment, Int. J. Electrochem. Sci., 2011, 6, 4593-4613.

118. F. El-Hajjaji, R.A. Belkhmima, B. Zerga, M. Sfaira, M. Taleb, M. Ebn Touhami, B. Hammouti, S.S. Al-Deyab and Eno Ebenso, Temperature Performance of a Thione Quinoxaline Compound as Mild Steel Corrosion Inhibitor in Hydrochloric Acid Medium, Int. J. Electrochem. Sci., 2014, 9, 4721-4731.

119. N.I. Podobaev and Ya.G. Avdeev, Temperature and Time Effects on the Acid Corrosion of Steel in the Presence of Acetylenic Inhibitor, Prot. Met., 2001, 37, no. 6, 529-533.

120. N.I. Podobaev and Ya.G. Avdeev, Effect of the Molecule Structure of Acetylene Compounds on the Kinetics of the Electrode Reactions of Iron in Hydrochloric and Sulfuric Acid, Prot. Met., 2002, 38, no. 1, 45-50.

121. Ya.G. Avdeev and N.I. Podobaev, The Role of Acrolein in the Inhibition of the Acid Corrosion of Iron with Propargyl Alcohol, Prot. Met., 2005, 41, no. 6, 592-596.

122. A. Frignani, C. Monticelli, F. Zucchi and G. Trabanelli, Acetylenic alcohols as inhibitors of iron acid corrosion. Improvement of the inhibition efficiency of a class of substances based on their action mechanism, Int. J. Corros. Scale Inhib., 2014, 3, no. 2, 105-119, doi: 10.17675/2305-6894-2014-3-2-105-119 
123. Ya.G. Avdeev, Yu.I. Kuznetsov and A.K. Buryak, Inhibition of steel corrosion by unsaturated aldehydes in solutions of mineral acids, Corros. Sci., 2013, 69, 50-60. doi: 10.1016/j.corsci.2012.11.016

124. A. Zarrouk, I. El Ouali, M. Bouachrine, B. Hammouti, Y. Ramli, E.M. Essassi, I. Warad, A. Aouniti and R. Salghi, Theoretical approach to the corrosion inhibition efficiency of some quinoxaline derivatives of steel in acid media using the DFT method, Res. Chem. Intermed., 2013, 39, no. 3, 1125-1133. doi: 10.1007/s11164-012-0671-1

125. Y. El Aoufir, H. Lgaz, H. Bourazmi, Y. Kerroum, Y. Ramli, A. Guenbour, R. Salghi, F. El-Hajjaji, B. Hammouti and H. Oudda, Quinoxaline Derivatives as Corrosion Inhibitors of Carbon Steel in Hydrochloridric Acid Media: Electrochemical, DFT and Monte Carlo simulations studies, J. Mater. Environ. Sci., 2016, 7, no. 12, 4330-4347.

126. H. Zarrok, A. Zarrouk, R. Salghi, H. Oudda, B. Hammouti, M. Ebn Touhami, M. Bouachrine and S. Boukhris, A Combined Experimental and Theoretical Study on the Corrosion Inhibition and Adsorption Behaviour of Quinoxaline Derivative During Carbon Steel Corrosion in Hydrochloric Acid, Port. Electrochim. Acta, 2012, 30, no. 6, 405-417. doi: 10.4152/pea.201206405

127. M. Elayyachy, B. Hammouti, A. El Idrissi and A. Aouniti, Adsorption and Corrosion Inhibition Behavior of C38 Steel by one Derivative of Quinoxaline in $1 \mathrm{M} \mathrm{HCl}$, Port. Electrochim. Acta, 2011, 29, no. 1, 57-68. doi: 10.4152/pea.201101057

128. J. Saranya, P. Sounthari, A. Kiruthuka, K. Parameswari and S. Chitra, The inhibiting effect of some Quinoxaline derivative towards mild steel corrosion in acid media: Chemical, Electrochemical and Theoretical studies, J. Mater. Environ. Sci., 2015, 6, no. 2, 425-444.

129. J. Saranya, P. Sounthari, A. Kiruthuka, G. Saranya, S. Yuvarani, K. Parameswari and S. Chitra, Experimental and Quantum Chemical Studies on the Inhibition Potential of Some Quinoxaline Derivatives for Mild Steel in Acid Media, Orient. J. Chem., 2014, 30, no. 4, 1719-1736. doi: 10.13005/ojc/300431

130. A. Zarrouk, B. Hammouti, A. Dafali, M. Bouachrine, H. Zarrok, S. Boukhris and S.S. Al-Deyab, A theoretical study on the inhibition efficiencies of some quinoxalines as corrosion inhibitors of copper in nitric acid, J. Saudi Chem. Soc., 2014, 18, 450-455. doi: 10.1016/j.jscs.2011.09.011

131. M. Yadav, S. Kumar, R.R. Sinha, I. Bahadur and E.E. Ebenso, New pyrimidine derivatives as efficient organic inhibitors on mild steel corrosion in acidic medium: Electrochemical, SEM, EDX, AFM and DFT studies, J. Mol. Liq., 2015, 211, 135-145. doi: $10.1016 /$ j.molliq.2015.06.063

132. Jiyaul Haque, K.R. Ansari, Vandana Srivastava, M.A. Quraishi and I.B. Obot, Pyrimidine derivatives as novel acidizing corrosion inhibitors for N80 steel useful for petroleum industry: A combined experimental and theoretical approach, J. Ind. Eng. Chem., 2017, 49, 176-188. doi: 10.1016/j.jiec.2017.01.025 
133. M.M. Kabanda, L.C. Murulana and E.E. Ebenso, Theoretical Studies on Phenazine and Related Compounds as Corrosion Inhibitors for Mild Steel in Sulphuric Acid Medium, Int. J. Electrochem. Sci., 2012, 7, 7179-7205.

134. I.B. Obot and N.O. Obi-Egbedi, 2,3-Diphenylbenzoquinoxaline: A new corrosion inhibitor for mild steel in sulphuric acid, Corros. Sci., 2010, 52, 282-285. doi: 10.1016/j.corsci.2009.09.013

135. I.B. Obot, N.O. Obi-Egbedi and N.W. Odozi, Acenaphtho [1,2-b] quinoxaline as a novel corrosion inhibitor for mild steel in $0,5 \mathrm{M} \mathrm{H}_{2} \mathrm{SO}_{4}$, Corros. Sci., 2010, 52, $923-$ 926. doi: 10.1016/j.corsci.2009.11.013

136. J. Saranya, P. Sounthari, K. Parameswari and S. Chitra, Acenaphtho[1,2-b]quinoxaline and acenaphtho[1,2- $b]$ pyrazine as corrosion inhibitors for mild steel in acid medium, Measurement, 2016, 77, 175-186. doi: 10.1016/j.measurement.2015.09.008

137. Ya.G. Avdeev, A.Yu. Luchkin, Yu.I. Kuznetsov, L.P. Kazansky and Yu.E. Pronin, Zashchitnoe posledeystvie ingibitora IFKhAN-92 pri korrozii stali v solyano- i sernokislykh sredakh (Protective aftereffect of IFKhAN-92 inhibitor on corrosion of steel in hydrochloric and sulfuric acid media), Korroz.: mater., zashch., 2012, no. 11, 20-25 (in Russian).

138. Ya.G. Avdeev, M.V. Tyurina, Yu.I. Kuznetsov, Yu.E. Pronin and L.P. Kazansky, Zashchita nizkouglerodistoy stali v rastvorakh fosfornoy kisloty ingibitorom IFKhAN92. Ch. 2 (Protection of low-carbon steel in solutions of phosphoric acid by IFHAN-92 inhibitor. Part 2), Korroz.: mater., zashch., 2013, no. 6, 17-23 (in Russian).

139. M.V. Tyurina, Ya.G. Avdeev, L.P. Kazanskii, A.Yu. Luchkin and O.A. Kireeva, Protection of Low-Carbon Steel from Corrosion in Hydrochloric Acid by 4-Substituted 1,2,4-Triazole, Prot. Met. Phys. Chem. Surf., 2016, 52, no. 7, 1147-1152. doi: 10.1134/S2070205116070157

140. Ya.G. Avdeev and A.Yu. Luchkin, Effect of IFKhAN-92 inhibitor on electrode reactions and corrosion of mild steels in hydrochloric and sulfuric acid solutions, Int. J. Corros. Scale Inhib., 2013, 2, no. 1, 53-66. doi: 10.17675/2305-6894-2013-2-1-053$\underline{066}$

141. Ya.G. Avdeev, D.S. Kuznetsov, M.V. Tyurina, S.V. Oleynik and M.A. Chekulaev, High-temperature inhibitors of stainless steel corrosion in sulfuric acid solutions, Int. J. Corros. Scale Inhib., 2017, 6, no. 1, 47-58. doi: 10.17675/2305-6894-2017-6-1-4

142. Ya.G. Avdeev, D.S. Kuznetsov, M.V. Tyurina, S.V. Oleynik and M.A. Chekulaev, High-temperature inhibitors of stainless steel corrosion in hydrochloric acid solutions, Int. J. Corros. Scale Inhib., 2017, 6, no. 2, 180-195. doi: 10.17675/2305-6894-2017-6$\underline{2-7}$

143. N.I. Podobayev and G.F. Semikolenov, Issledovaniye tormozyashchego deystviya na korroziyu uglerodistoy stali $\mathrm{v}$ sernoi kislote smesi benzilaniliniikhlorida i tribenziltrigidro-sim-triazina (Investigation of the inhibitory effect on the corrosion of carbon steel in sulfuric acid of a mixture of benzylanilinium chloride and 
tribenzyltrihydro-sim-triazine)," Zhurnal fizicheskoy khimii (Russ. J. Phys. Chem. A), 1974, 48, no. 5, 1269-1271 (in Russian).

144. F.B. Growcock and W.W. Frenier, Kinetics of Steel Corrosion in Hydrochloric Acid Inhibited with trans-Cinnamaldehyde, J. Electrochem. Soc., 1988, 135, no. 4, 817-822. doi: $10.1149 / 1.2095783$

145. F.B. Growcock and V.R. Lopp, Film Formation on Steel in Cinnamaldehyde Inhibited Hydrochloric Acid, Corrosion, 1988, 44, no. 4, 248-254. doi: $\underline{10.5006 / 1.3583933}$

146. W.W. Frenier, F.B. Growcock and V.R. Lopp, $\alpha$-Alkenylphenones - A New Class of Acid Corrosion Inhibitors, Corrosion, 1988, 44, no. 9, 590-598. doi: $\underline{10.5006 / 1.3584970}$

147. F.B. Growcock, Corrosion Kinetics of J55 Steel in Hydrochloric Acid Inhibited with Benzoyl Allyl Alcohol, Corrosion, 1989, 45, no. 5, 393-401. doi: 10.5006/1.3582034

148. F.B. Growcock, V.R. Lopp and R.J. Jasinski, Corrosion Protection of Oilfield Steel with 1-Phenyl-2-propyn-1-ol, J. Electrochem. Soc., 1988, 135, no. 4, 823-827.

149. W.W. Frenier and D.G. Hill, Green inhibitors development and applications for aqueous systems, in Reviews on Corrosion Inhibitor Science and Technology, Ed. A. Raman, NACE International, USA, Houston, Texas, 2004, Vol. 3, pp. 6-1 - 6-40.

150. N.I. Podobaev and V.V. Vasil'yev, Issledovaniye zashchitnogo deystviya azotsoderzhashchikh $\mathrm{i}$ atsetilenovykh ingibitorov korrozii stali i ikh smesey v solyanoy kislote $\mathrm{v}$ zavisimosti ot temperatury $\left(\right.$ do $250^{\circ} \mathrm{C}$ ) i davleniya (do $700 \mathrm{~atm}$.) (Investigation of the protective effect of nitrogen-containing and acetylene corrosion inhibitors of steel and their mixtures in hydrochloric acid as a function of temperature (up to $250^{\circ} \mathrm{C}$ ) and pressure (up to $700 \mathrm{~atm}$.)), in Ingibitory korrozii metallov (Metal corrosion inhibitors), MGPI im. V.I. Lenina, Moscow, 1969, Issue 3, pp. 72-82 (in Russian). 